\title{
Kategoria aspektu w języku polskim i niemieckim. Analiza translatywna
}

\author{
The aspect category in Polish and German. \\ A translative analysis
}

\author{
Anna Nadachewicz \\ anadachewicz@o2.pl
}

\begin{abstract}
The category of aspect is usually viewed as an obligatory grammatical (morphological) verbal category existing in the Slavic, but not in the Germanic languages. This article considers possibilities of expressing aspectual meanings in German as one of the so-called aspectless languages. It presents a translative comparative analysis of the Polish novel "Wysoki Zamek" by Stanisław Lem and it's translation into German. It studies language means used for expressing aspect in the Polish text and their potential equivalents in the German translation. As shown in the analysis, Polish verbs are not the only carriers of aspectual meanings. As a result of complex bilateral relationships between aspect and Aktionsart (kind of action) some non-verbal means, e.g. adverbials, conjunctions and nouns being objects, also may be considered as indicators of aspectual meanings in Polish. This study argues for equivalent nonverbal means, semantics of verbs and verbal phrases as well as fixed syntagms being potential carriers of aspectual meanings in German as in a language with no morphological category of aspect.
\end{abstract}

\section{Wstęp}

W tradycyjnej aspektologii język niemiecki określany jest mianem bezaspektowego. Idea bezaspektowości języków germańskich po raz pierwszy pojawiła się w 1927 r. u Porziga. Stwierdził on: „Ob es in einer gegebenen Sprache den Aspekt gibt, ist nur zu erkennen durch die Morphologie; denn jede Bedeutungskategorie muss morphologisch fassbar sein" (za: Młynarczyk 2004: 37). Dla Porziga bezaspektowość języków germańskich oznaczała zatem nieistnienie w nich nie tylko morfologicznej, lecz także znaczeniowej kategorii aspektu, tj. niemożność wyrażania w nich znaczeń aspektowych. Dziś trudno już znaleźć kontynuatorów myśli Porziga. Większość badaczy dokonała bowiem swoistego przeobrażenia pojęcia bezaspektowości, charakteryzując ją jako brak wyłącznie morfologicznej, nie zaś semantycznej kategorii aspektu (por. Andersson 2004: 10). Zatem mimo iż język niemiecki nadal bywa nazywany językiem bezaspektowym, dzisiejsze rozumienie tego określenia jest już całkiem odmienne od pierwotnego.

Brak w języku niemieckim morfologicznej kategorii aspektu spowodował, iż część autorów (m.in. Czarnecki 1998, Andersson 2004, Ballweg 2004) nie samą kategorię aspektu, lecz całą 
kategorię aspektualności ${ }^{1}$ czyni podstawą badań porównawczych pomiędzy językami słowiańskimi a tzw. językami bezaspektowymi. Jak bowiem stwierdza Schwall (1991: 98):

Das 'Gemeinte', das in den slavischen Sprachen mittels verschiedener Aspekte und Aktionsarten ausgedrückt werden kann, vermag ein Deutscher, ein Spanier etc. mit gewissen Abstrichen zu empfinden und wiederzugeben. Der Mangel an explizierter grammatischmorphologischer Kennzeichnung semantischer Qualitäten in den nicht-slavischen Sprachen bewirkt eine größere Abhängigkeit von Kontext und Situation; was im Russischen mit einem Verb vermittels Aspektdifferenzierung [...] ausgedrückt werden kann, muss im Deutschen ggf. mit zwei verschiedenen Verben oder mit Hilfe von Adverbien wiedergegeben werden. Auf der Ausdrucksseite liegen also heterogene Techniken und Strukturen vor.

Dość radykalne stanowisko w kwestii realizacji znaczeń aspektowych w języku niemieckim zajmuje Cockiewicz, który twierdzi, że istniejące w nim sposoby wyrażania opozycji dokonaności i niedokonaności mają wprawdzie charakter nieregularny, jednak „Te rozmaite: morfologiczne (czasy), składniowe (konstrukcje peryfrastyczne, następstwo czasów) i leksykalne środki są w języku niemieckim funkcjonalnymi odpowiednikami polskiego aspektu, gdyż pozwalają one znaleźć wyraz językowy dla k a ż d e j [podkreślenie moje - AN] polskiej opozycji aspektowej” (Cockiewicz 1992: 140).

Brak morfologicznej kategorii aspektu w języku niemieckim jest powszechnie uznanym i niezaprzeczalnym faktem językowym. Czy oznacza to jednak - jak sugeruje m.in. Wojtasiewicz (1996: 24 i n.) - że każde thumaczenie tekstu polskiego czy rosyjskiego na język niemiecki wiąże się z tak ogromnymi stratami poznawczymi dla odbiorców przekładu? Czy rzeczywiście użytkownik języka niemieckiego nie uzyska informacji, czy daną czynność wykonywano, czy też wykonano?

Zdaniem autorki niniejszej pracy stwierdzenie, iż brak morfologicznej kategorii aspektu w języku niemieckim uniemożliwia wyrażanie w nim znaczeń aspektowych, oznaczałoby przyłączenie się do zwolenników determinizmu językowego ${ }^{2}$. Przyjmując, iż w języku niemieckim niemożliwe jest wyrażenie znaczeń aspektowych, musielibyśmy uznać za bezcelowe jakiekolwiek próby translacji. Równocześnie należałoby zrezygnować z nauczania i uczenia się języków obcych. Jednak licząca już kilka tysięcy lat $\mathrm{i}$ uprawiana $\mathrm{z}$ powodzeniem praktyka thumaczenia sama świadczy o swej celowości. Sama broni się również dydaktyka języków obcych. Stąd tak silne przeświadczenie autorki o istnieniu w języku niemieckim środków językowych - być może bardzo odmiennych od tych, które realizują znaczenia aspektowe w języku polskim - pozwalających wyrazić dokonaność i niedokonaność. I stąd cel niniejszej pracy, jakim jest ustalenie możliwości przekładu polskich fraz aspektowych na nazywany bezaspektowym język niemiecki.

\section{Uwagi metodologiczne}

Jako materiał badań nad sposobami realizacji znaczeń aspektowych we współczesnym języku niemieckim w procesie thumaczenia $\mathrm{z}$ języka polskiego wybrana została powieść autobiograficzna Stanisława Lema pt. Wysoki Zamek, która ukazała się w 1968 r. nakładem warszawskiego wydawnictwa Czytelnik, oraz dokonane na podstawie tegoż wydania tłumaczenie na język niemiecki autorstwa Caesara Rymarowicza pt. Das Hohe Schloß, które ukazało się w roku 1990 nakładem berlińskiego wydawnictwa Suhrkamp Verlag. Na wybór materiałów badawczych miało wpływ kilka kwestii, wśród których należy wymienić przede wszystkim kwestie związane $\mathrm{z}$ występującymi w tekście polskim i jego niemieckim thumaczeniu formami czasów gramatycznych. Stanowiący zapis wspomnień z dzieciństwa autora Wysoki Zamek napisany został bowiem przede wszystkim w czasie przeszłym, przez co stanowi doskonałą bazę dla rozważenia tak często

\footnotetext{
${ }^{1} \mathrm{~W}$ niniejszej pracy aspektualność rozumiana jest jako kategoria funkcjonalno-semantyczna, posiadająca różnorodne środki językowe dla określania charakteru przebiegu czynności w czasie. Za subkategorie aspektualności uznane zostały gramatyczno-leksykalno-kontekstowe kategorie aspektu oraz akcjonalności. W ramach kategorii akcjonalności wyróżniono kategorię posiadających wykładniki formalne rodzajów czynności oraz kategorię pozbawionego wykładników formalnych, tj. inherentnego, akcjonalnego znaczenia leksykalnego czasownika (tzw. Verbalcharakter).

${ }^{2}$ Rozumianego jako radykalna wersja teorii relatywizmu językowego autorstwa E. Sapira i B. Whorfa.
} 
dyskutowanej w literaturze przedmiotu funkcji aspektowej form niemieckich czasów gramatycznych. Należy bowiem zaznaczyć, iż część badaczy widzi w nich sygnifikatory znaczeń aspektowych, stwierdzając odpowiedniość pomiędzy znaczeniem niemieckiego czasu Perfekt a słowiańskim aspektem dokonanym oraz pomiędzy znaczeniem niemieckiego czasu Präteritum a słowiańskim aspektem niedokonanym (por. m.in. Flämig 1970, Brinkmann 1971).

$\mathrm{Z}$ uwagi na przyjęte $\mathrm{w}$ niniejszej pracy założenie, zgodnie z którym aspekt nie jest kategorią zaledwie czasownikową, tj. realizacja aspektu ma miejsce równocześnie na poziomie czasownikowym i zdaniowym, za punkt wyjścia badań przyjęto znaczenie aspektowe polskiego zdania. W badaniu uwzględniono oczywiście wyłącznie te zdania, których znaczenie aspektowe można było ustalić. W szczególności pominięto wypowiedzenia pozbawione form czasownikowych oraz zdania sformułowane w trybie przypuszczającym. $\mathrm{Z}$ uwagi na fakt, iż zdania sformułowane w czasie teraźniejszym zawsze niosą znaczenie niedokonane, kategoria teraźniejszości nie została poddana badaniu, jako niewykazująca opozycji w zakresie aspektu.

Uznając aspekt za ponadczasownikową kategorię gramatyczno-leksykalno-kontekstową, wyróżniono trzy etapy konstytuowania się znaczenia aspektowego polskiego zdania - etap czasownikowy, etap nieczasownikowych części zdania oraz etap kontekstowy. Poczynione obserwacje wskazują na hierarchiczne uporządkowanie ww. etapów konstytuowania się znaczenia aspektowego zdania, co powoduje, iż w przypadku konfliktu między znaczeniami aspektowymi na poszczególnych poziomach aspekt niższego poziomu może zostać zneutralizowany przez aspekt poziomu wyższego.

Pierwszy etap ustalania znaczenia aspektowego polskiego zdania stanowi określenie znaczenia aspektowego czasownika stanowiącego jego orzeczenie. Kolejnym etapem jest rozważenie występujących $\mathrm{w}$ zdaniu nieczasownikowych części mowy jako ewentualnych nośników znaczeń aspektowych. W szczególności zostają tu uwzględnione formy rzeczowników w funkcji dopełnienia, okoliczniki oraz spójniki wprowadzające zdanie poboczne ${ }^{3}$. Ostatni etap ustalania znaczenia aspektowego polskiego zdania stanowi odwołanie się do znaczenia całego fragmentu tekstu, w jakim dane zdanie zostało umieszczone, np. całego akapitu. W szczególności zostaje tu uwzględnione znaczenie aspektowe innych czasowników będących orzeczeniami we fragmencie tekstu stanowiącym całość znaczeniową (myślową bądź sytuacyjna) oraz inne, nieczasownikowe części mowy, mogące stanowić indykatory aspektowe.

W niniejszej pracy termin 'indykatory aspektowe' używany jest w odniesieniu do środków gramatycznych, leksykalnych oraz leksykalno-gramatycznych pozwalających ustalić przynależność odnośnego zdania do odpowiedniej kategorii aspektowej. Nie obejmuje on kontekstu językowego i sytuacyjnego, w przypadku których nie można mówić o odpowiedniości pomiędzy znaczeniem aspektowym zdania a obecnością pewnych identyfikowalnych zabiegów językowych.

W celu uniknięcia niejasności terminologicznych w całej pracy zastosowane zostały następujące rozwiązania: wyróżniono dwa znaczenia aspektowe - dokonaność i niedokonaność. Określenie 'znaczenia akcjonalne' używane jest w odniesieniu do środków językowych realizujących akcjonalność, tj. takie znaczenia jak iteratywność, delimitatywność, perduratywność itp. Mówiąc ogólnie o funkcjach środków językowych określających charakter przebiegu czynności w czasie, tj. nie różnicując znaczenia aspektowego i akcjonalnego, używam określenia 'znaczenie aspektualne'.

\section{Niemieckie czasy gramatyczne a aspekt w języku polskim}

Jak wspomniano, niemieckie czasy gramatyczne budzą wiele kontrowersji wśród aspektologów, z których część skłonna jest widzieć w nich nośniki znaczeń aspektowych ${ }^{4}$. Szczególnie wiele dyskusji wywołują czasy o formie analitycznej, przede wszystkim Perfekt i Plusquamperfekt, oraz opozycja pomiędzy czasowymi formami analitycznymi i syntetycznymi - tu zwłaszcza między

\footnotetext{
${ }^{3}$ Wszystkie wymienione środki językowe zostały uznane za nośniki znaczeń aspektowych w oparciu o ich charakterystykę przedstawioną w Stowniku języka polskiego (Szymczak (Ed.) 1988).

${ }^{4}$ M.in. Comrie (1976), Ehrich i Vater (1989), Vater (2000), Baudot (2004a), Schanen (2004).
} 
czasami Perfekt i Präteritum - o czym świadczyć może chociażby dość rozpowszechniony w niemieckim językoznawstwie podział paradygmatu czasownikowego na Verlaufsstufe (Präsens I Präteritum) i Vollzugsstufe (Perfekt / Plusquamperfekt), tj. pogląd o ujmowaniu zdarzenia w jego trwaniu (przebiegu) przez formy czasów Präsens i Präteritum i jako czynności zakończonej przez formy czasów Perfekt i Plusquamperfekt (por. Andersson 2004: 6-10).

Przedstawiona poniżej analiza form czasów gramatycznych, których obecność stwierdzono w niemieckim materiale badawczym, ma na celu uzasadnienie, dlaczego tylko część z nich została uznana za indykatory aspektowe. Wykaże ona bowiem brak odpowiedniości pomiędzy obecnością w niemieckim zdaniu form poszczególnych czasów gramatycznych a znaczeniem aspektowym jego polskiego odpowiednika, zwłaszcza zaś pomiędzy obecnością form czasów analitycznych w zdaniu niemieckim a dokonanym znaczeniem zdania polskiego oraz pomiędzy obecnością form czasu Präteritum w zdaniu niemieckim a niedokonanym znaczeniem odpowiednika polskiego.

Jak wspomniano, jako zapis wspomnień Wysoki Zamek napisany został przede wszystkim w czasie przeszłym. Zgodnie $\mathrm{z}$ konwencją ogromna część wydarzeń przedstawiona jest $\mathrm{z}$ perspektywy wewnętrznej, tj. z perspektywy aspektu niedokonanego. $Z$ uwagi na fakt, iż $w$ niemieckim thumaczeniu utworu dominującym czasem gramatycznym w partiach odnoszących się do wydarzeń mających miejsce w przeszłości jest czas Präteritum, którego formy występują w niemieckich odpowiednikach polskich zdań zarówno niedokonanych, jak i dokonanych, tj. niezależnie od ich znaczenia aspektowego, został on potraktowany jako neutralny z punktu widzenia znaczenia aspektowego zdania przeszłego i nie jest zaliczany do indykatorów aspektowych. Ponadto w niemieckim thumaczeniu utworu wystapiły formy czasów Perfekt, Plusquamperfekt, Präsens oraz Futur I. Z uwagi na fakt, iż w poddanym badaniu tekście niemieckim nie wystapiły formy czasu Futur II, jego ewentualne znaczenia aspektualne nie zostaną tu omówione.

\section{Formy czasu Präsens}

Formy czasu Präsens mogą wystapić w czterech wariantach znaczeniowych (por. Helbig, Buscha 2001: 130-132):

a. znaczenie teraźniejsze aktualne, tj. oznaczanie zdarzenia aktualnie mającego miejsce (tzw. aktuelles Präsens), np. Das Kind spielt im Wohnzimmer,

b. znaczenie atemporalne, tj. oznaczanie ogólnie obowiązujących stanów rzeczy (tzw. generelles Präsens, atemporales Präsens), np. Die Erde bewegt sich um die Sonne,

c. znaczenie przyszłe, np. In einem Monat haben die Kinder Ferien, które automatycznie uzyskują zdania sformułowane $\mathrm{w}$ czasie Präsens zawierające czasowniki terminatywne, tj. wyrażające ograniczenie czasowe przebiegu akcji lub zmianę stanu, np. Wir treffen uns am Bahnhof,

d. znaczenie przeszłe (tzw. historisches Präsens), w przypadku którego przeszła interpretacja zdania następuje wskutek obecności w nim okolicznika czasu bądź poprzez umieszczenie go w odpowiednim kontekście, np. 1914 beginnt der Erste Weltkrieg: „Diese Variante kommt im Bericht und in der Erörterung kaum vor, sondern ist auf die Erzählung, auf die Beschreibung historischer Tatsachen und auf die Dichtersprache beschränkt; dort dient sie dazu, Vergangenes besonders lebendig zu gestalten und zu 'vergegenwärtigen"' (Helbig, Buscha 2001: 131).

Jak wspomniano, w przeprowadzonym badaniu nie zostały uwzględnione zdania o znaczeniu teraźniejszym, jako że kategoria teraźniejszości - jako zawsze powiązana z niedokonanością - nie wykazuje opozycji w zakresie aspektu, tj. nie zostało uwzględnione pierwsze oraz drugie $\mathrm{z}$ przytoczonych wyżej znaczeń czasu Präsens. Odnośnie użycia form czasu Präsens dla oznaczenia zdarzenia przeszłego należy zauważyć, że nie wywiera ono wpływu na znaczenie aspektualne zdania, lecz ma wyłącznie wartość stylistyczną. Zatem jedynie w przypadku użycia form czasu Präsens w odniesieniu do zdarzenia przyszłego, można mówić o jego zabarwieniu aspektualnym tym bardziej, że zdanie w czasie Präsens automatycznie uzyskuje znaczenie przyszłe w przypadku czasowników terminatywnych, tj. wyrażających ograniczenie czasowe akcji lub zmianę stanu. 
Jednak de facto chodzi tu o fazowe rodzaje czynności ${ }^{5}$, a więc znaczenia akcjonalne, nie zaś aspektowe, w związku z czym również użycie form czasu Präsens w znaczeniu przyszłym nie zostało uznane za indykator aspektowy.

\section{Formy czasu Präteritum}

Helbig i Buscha (2001: 132-134) wymieniają jedno główne znaczenie czasu Präteritum, jakim jest oznaczanie zdarzeń mających miejsce w przeszłości. Jak wspomniano wyżej, czas Präteritum w znaczeniu przeszłym został potraktowany jako neutralny z punktu widzenia znaczenia aspektowego zdania i w ramach kategorii przeszłości nie jest zaliczany do indykatorów aspektowych.

Helbig i Buscha (2001: 133) wskazują również na sporadyczny wariant znaczeniowy czasu Präteritum w przypadku tzw. 'erlebte Rede' bądź 'erlebte Reflexion', tj. w szczególnym typie mowy zależnej, w którym rozmowy bądź myśli relacjonowane są z perspektywy agensa, np. Er fragte sich: Wird er sie in diesem Gewimmel wohl finden? $\rightarrow$ Ob er sie wohl fand in diesem Gewimmel? Jak stwierdzają autorzy: „In der 'erlebten Rede' wird das Präteritum manchmal als Stilmittel benutzt, um gegenwärtige Sachverhalte zu bezeichnen. [...] In referierender Verwendung kommt das Präteritum in seltenen Fällen nicht nur zur Bezeichnung gegenwärtiger Sachverhalte, sondern auch zur Bezeichnung zukünftiger Sachverhalte vor [...]“" (Helbig, Buscha 2001: 133). Należy jednak zauważyć, że ów wariant znaczeniowy czasu Präteritum ma przede wszystkim wartość stylistyczną, w szczególności zaś nie wpływa na znaczenie aspektualne zdania. Wskutek tego nie został on zaliczony do indykatorów aspektowych.

\section{Formy czasu Perfekt}

Formy czasu Perfekt mogą wystąpić w czterech wariantach znaczeniowych (por. Helbig, Buscha 2001: 135-136):

a. znaczenie przeszłe nierezultatywne, w którym formy czasów Perfekt i Präteritum moga występować zamiennie,

b. znaczenie przeszłe rezultatywne, w którym forma czasu Perfekt nie może zostać zastapiona formą czasu Präteritum: „Das Perfekt drückt in dieser Bedeutungsvariante vergangene Sachverhalte aus, die einen für die Sprechzeit relevanten Zustand implizieren, der für die Kommunikation wesentlicher ist als die in der Vergangenheit liegende Aktzeit" (Helbig, Buscha 2001: 135).,

c. znaczenie przyszłe: „Das Perfekt drückt in dieser Bedeutungsvariante zukünftige Sachverhalte aus, die man sich unter einem bestimmten Zeitpunkt (als Perspektive der Betrachtzeit) als abgeschlossen vorstellt“ (Helbig, Buscha 2001: 136). W tym znaczeniu czasu Perfekt obowiązkowa jest obecność w zdaniu dodatkowego okolicznika czasu, wskazującego na jego przyszłe odniesienie, np. morgen, bald, bis Sonntag itd.,

d. znaczenie atemporalne, tj. oznaczanie ogólnie obowiązujących stanów rzeczy, w przypadku którego forma czasu Perfekt może zostać zastapiona formą tzw. aktuelles Präsens.

W materiale badawczym formy czasu Perfekt ani razu nie pojawiły się w zdaniach wyrażających ogólnie obowiązujące stany rzeczy, tj. nie wystąpiło czwarte spośród wyżej wymienionych jego znaczeń. We wszystkich zatem przypadkach, w których formy czasu Perfekt mogłyby zostać uznane za indykatory aspektowe, zdanie miało znaczenie przeszłe (przytoczone wyżej znaczenia a oraz b) bądź przyszłe (przytoczone wyżej znaczenie c).

Fakt, iż w przypadku znaczenia przeszłego nierezultatywnego formy czasów Perfekt i Präteritum mogą występować zamiennie, wskazuje na brak związków pomiędzy znaczeniem aspektowym przeszłego zdania polskiego a występującą $\mathrm{w}$ jego niemieckim odpowiedniku formą czasu gramatycznego, wskutek czego nierezultatywne formy czasu Perfekt zostały wyłączone spośród indykatorów aspektowych.

Czas Perfekt w znaczeniu rezultatywnym oznacza zdarzenie przeszłe, którego skutkiem jest pewien istotny dla momentu mówienia stan rzeczy, z komunikacyjnego punktu widzenia ważniejszy niż sam moment zdarzenia (por. Helbig, Buscha 2001: 135). Ponieważ w tzw. językach aspektowych rezultatywność jest trwale związana z dokonanością, będące nośnikami znaczenia

\footnotetext{
${ }^{5} \mathrm{Tj}$. ingresywność, egresywność, mutatywność (transformatywność, tj. znaczenie zmiany stanu) oraz kauzatywność (por. Helbig, Buscha 2001: 61-62).
} 
rezultatywnego formy czasu Perfekt mogą wykazywać ewentualne powiązania jedynie ze znaczeniem dokonanym zdania. Jak wskazują Helbig i Buscha, rezultatywne użycie czasu Perfekt ograniczone jest wyłącznie do czasowników transformatywnych (mutatywnych), gdyż „,...] nur diese den Übergang zu einem Folgezustand ausdrücken" (Helbig, Buscha 2001: 136). Należy jednak zauważyć, iż zależność pomiędzy rezultatywnym znaczeniem formy czasu Perfekt a transformatywnym charakterem tworzącego ją czasownika jest zależnością jednokierunkową, tzn. wszystkie czasowniki tworzące rezultatywne formy czasu Perfekt muszą mieć charakter transformatywny, ale nie odwrotnie, tj. transformatywny charakter czasownika nie musi skutkować rezultatywnym znaczeniem jego formy czasu Perfekt. Oznacza to, że czasowniki transformatywne mogą występować $\mathrm{w}$ zdaniach nierezultatywnych, m.in. duratywnych, tj. niedokonanych, np. Während sie das Haus abgerissen haben, haben sie die ganze Zeit auf Spuren der ursprünglichen Bauweise geachtet ${ }^{6}$. Zatem sama obecność w zdaniu niemieckim formy czasu Perfekt czasownika transformatywnego nie decyduje o dokonanym znaczeniu jego polskiego odpowiednika. Dla jednoznacznego ustalenia znaczenia aspektowego takiego zdania konieczne jest uwzględnienie obecnych w nim nieczasownikowych części mowy jako ewentualnych nośników znaczeń aspektowych ${ }^{7}$ oraz kontekstu sytuacyjnego.

Jak wspomniano, formy czasu Perfekt mogą być również używane dla oznaczenia zdarzenia przyszłego, które w pewnym momencie w przyszłości postrzegane będzie jako zakończone osiagnnięciem pewnego rezultatu. Tak użyta forma czasu Perfekt rzeczywiście zdaje się być indykatorem dokonanego znaczenia aspektowego zdania, bowiem czynność mająca dopiero mieć miejsce, która w przyszłości ma być postrzegana jako dokonana, już w momencie mówienia musi być wyobrażona jako dokonana. Przy czym znaczenie przyszłe nadaje takim zdaniom dopiero obligatoryjny okolicznik czasu, co powoduje, że sama forma czasu Perfekt nie wskazuje na odniesienie zdania do zdarzenia przyszłego. Stąd formy czasu Perfekt użyte dla oznaczenia zdarzenia mającego mieć miejsce w przyszłości należy uznać za niesamodzielne indykatory dokonaności.

Podsumowując, związek pomiędzy znaczeniem aspektowym zdania polskiego a użyciem w jego niemieckim odpowiedniku form czasu Perfekt widoczny jest w dwóch zaledwie przypadkach, tj. tzw. rezultatywnego czasu Perfekt oraz jego użycia dla oznaczania zdarzeń mających mieć miejsce $\mathrm{w}$ przyszłości. Jednak ponieważ $\mathrm{w}$ obu przypadkach nie można na podstawie samej obecności w zdaniu form czasu Perfekt stwierdzić, czy zdanie to ma znaczenie dokonane, czy niedokonane, zostały one uznane za niesamodzielne indykatory dokonaności.

\section{Formy czasu Plusquamperfekt}

Czas Plusquamperfekt może wystapić w dwóch wariantach znaczeniowych (por. Helbig, Buscha 2001: 136-137):

a. znaczenie zaprzeszłe, w którym forma czasu Plusquamperfekt nie może zostać zastapiona formą czasu Perfekt,

b. znaczenie przeszłe rezultatywne, w którym forma czasu Plusquamperfekt może zostać zastąpiona formą tzw. rezultatywnego czasu Perfekt.

W materiale badawczym formy czasu Plusquamperfekt pojawiły się w obu przytoczonych tu znaczeniach, tj. zarówno dla wyrażenia zdarzenia zaprzeszłego, jak również $\mathrm{w}$ znaczeniu rezultatywnym. W ogromnej większości zdań formy czasu Plusquamperfekt zostały użyte dla oznaczenia zdarzeń zaprzeszłych, kiedy to brak jest identyfikowalnych związków pomiędzy ich obecnością w zdaniu niemieckim a znaczeniem aspektowym polskiego odpowiednika zdaniowego. Ponieważ nierezultatywne użycie form czasu Plusquamperfekt służy jedynie uporządkowaniu zdarzeń przeszłych na osi czasu, zostało ono wyłączone spośród indykatorów aspektowych. Trzeba bowiem stwierdzić, iż czynność zaprzeszła nie musi być dokonana, choć często rzeczywiście tak się dzieje. Wniosek ten potwierdzają wyniki przeprowadzonych badań, w których mamy do

\footnotetext{
${ }^{6}$ Przykład za: Andersson 2004: 7.

${ }^{7} \mathrm{~W}$ przytoczonym za Anderssonem przykładzie elementem nieczasownikowym wnoszącym znaczenie duratywności, a wskutek tego - niedokonaności, jest spójnik zdania okolicznikowego czasu während.
} 
czynienia zarówno $\mathrm{z}$ formami czasu Plusquamperfekt wyrażającymi zaprzeszłą czynność dokonaną, jak i zaprzeszłą czynność niedokonaną.

Jedynie zatem w przypadku form czasu Plusquamperfekt w znaczeniu rezultatywnym można by mówić o znaczeniu aspektualnym. Z uwagi na fakt, iż forma czasu Plusquamperfekt w znaczeniu rezultatywnym może zostać zastąpiona formą tzw. rezultatywnego czasu Perfekt, wszystkie spostrzeżenia dotyczące rezultatywnego użycia czasu Perfekt, jakie zostały przedstawione powyżej, w równej mierze odnoszą się do rezultatywnie użytych form czasu Plusquamperfekt.

Podobnie jak czas Perfekt w znaczeniu rezultatywnym, tzw. rezultatywny Plusquamperfekt oznacza przeszłe zdarzenia implikujące istotne dla momentu mówienia stany rzeczy, które z komunikacyjnego punktu widzenia są ważniejsze niż sam moment zdarzenia, co pozwala wnioskować o jego ewentualnych powiązaniach jedynie ze znaczeniem dokonanym zdania. Podobnie jak w przypadku tzw. rezultatywnego czasu Perfekt, rezultatywne użycie czasu Plusquamperfekt ograniczone jest wyłącznie do czasowników transformatywnych (mutatywnych), oznaczających zmianę prowadzącą do owego stanu będącego skutkiem zdarzenia. Przy czym również w tym przypadku brak jest dwukierunkowej zależności pomiędzy rezultatywnym znaczeniem formy czasu Plusquamperfekt a transformatywnym charakterem tworzącego ja czasownika. Oznacza to, że czasowniki transformatywne mogą występować zarówno w zdaniach rezultatywnych, jak i nierezultatywnych. Dla jednoznacznego ustalenia znaczenia aspektowego zdania zawierającego formę czasu Plusquamperfekt czasownika transformatywnego konieczne jest zatem uwzględnienie obecnych $\mathrm{w}$ nim nieczasownikowych części mowy jako ewentualnych nośników znaczeń aspektowych oraz kontekstu. Ponieważ na podstawie samej obecności w zdaniu form czasu Plusquamperfekt czasownika transformatywnego nie można stwierdzić, czy zdanie to ma znaczenie dokonane, czy niedokonane, mogą one zostać uznane jedynie za niesamodzielne indykatory dokonanego znaczenia aspektowego zdania.

\section{Formy czasu Futur I}

Czas Futur I może wystapić w trzech wariantach znaczeniowych (por. Helbig, Buscha 2001: 132, 137-139):

a. oznaczanie przypuszczalnego zdarzenia w teraźniejszości, w którym to przypadku formy czasu Futur I mogą zostać zastapione przez formy tzw. aktuelles Präsens, o ile w zdaniu w czasie teraźniejszym wystapi dodatkowy element wyrażający modalność,

b. oznaczanie ogólnie obowiązujących stanów rzeczy, w którym to znaczeniu formy czasu Futur I mogą zostać zastapione formami tzw. generelles Präsens.

c. oznaczanie zdarzenia przyszłego, w którym to przypadku formy czasu Futur I mogą zostać zastapione formami czasu Präsens. Znaczenie przyszłe automatycznie uzyskują zdania sformułowane w czasie Futur I zawierające czasowniki terminatywne, np. Er wird einen Brief bekommen.

W materiale badawczym formy czasu Futur I ani razu nie pojawiły się w niemieckich odpowiednikach zdań polskich oznaczających przypuszczalne zdarzenia $\mathrm{w}$ teraźniejszości, ani wyrażających ogólnie obowiązujące stany rzeczy, tj. nie wystąpiło pierwsze oraz drugie spośród wyżej wymienionych jego znaczeń. Zatem jedynie w przypadku użycia form czasu Futur I dla oznaczenia zdarzenia przyszłego możemy mówić o jakimkolwiek znaczeniu aspektualnym, jako że zdanie sformułowane w czasie Futur I automatycznie uzyskuje znaczenie przyszłe w przypadku obecności czasowników terminatywnych, tj. wyrażających ograniczenie czasowe przebiegu akcji lub zmianę stanu. Mamy tu zatem do czynienia z analogiczną sytuacją jak w przypadku zdań w czasie Präsens zawierających czasowniki terminatywne. Chodzi tu więc w zasadzie o znaczenia akcjonalne, dokładniej - fazowe rodzaje czynności, nie zaś o znaczenia aspektowe, w związku z czym formy czasu Futur $I \mathrm{w}$ znaczeniu przyszłym również nie zostały uznane za indykatory aspektowe.

Podsumowując, związek pomiędzy znaczeniem aspektowym zdania polskiego a użyciem w jego niemieckim odpowiedniku zdaniowym form czasu gramatycznego zachodzi w zaledwie trzech przypadkach:

1. form czasu Perfekt dla oznaczania zdarzeń mających mieć miejsce w przyszłości, 
2. form tzw. rezultatywnego czasu Perfekt,

3. form tzw. rezultatywnego czasu Plusquamperfekt.

$\mathrm{Z}$ uwagi na fakt, iż $\mathrm{w}$ żadnym $\mathrm{z}$ ww. przypadków o znaczeniu aspektowym zdania polskiego nie można wnioskować na podstawie samej obecności formy czasu gramatycznego w jego niemieckim odpowiedniku, wszystkie ww. formy zostały uznane za niesamodzielne indykatory dokonaności.

\section{Niemieckie odpowiedniki translatywne polskich fraz aspektowych}

Przedstawiona poniżej analiza aspektowa polskich i niemieckich zdań została podzielona na dwie części: poświęconą polskim zdaniom dokonanym i ich niemieckim odpowiednikom oraz prezentująca polskie zdania niedokonane i ich niemieckie odpowiedniki. Jak wspomniano, punktem wyjścia niniejszych badań są polskie zdania i obecne w nich środki służące realizacji znaczeń aspektowych. Drugi etap rozważań stanowią niemieckie odpowiedniki tychże zdań polskich i obecne w nich potencjalne nośniki dokonaności bądź niedokonaności.

$\mathrm{W}$ przedstawionych poniżej przykładach polskich i niemieckich zdań każdy typ indykatorów aspektowych zostanie zademonstrowany na jednym przykładzie. Podwójną linią podkreślony zostanie aktualnie przedstawiany typ indykatora, natomiast pojedynczą linią zostaną podkreślone inne indykatory tego samego znaczenia aspektowego. Ponieważ słowiański czasownik w formie osobowej jako nośnik znaczenia aspektowego nie budzi większych kontrowersji, jego funkcja aspektowa nie będzie omawiana w przedstawionych poniżej przykładach. Pozostałe indykatory zostaną zaopatrzone w krótki komentarz. Wszystkie przykłady zawarte w komentarzach pochodzą od autorki niniejszej pracy.

Znaczną część polskich zdań wyjściowych stanowiły zdania wielokrotnie złożone, w których równocześnie realizowane były oba znaczenia aspektowe. Jeśli zdania składowe zdania złożonego były nośnikami różnych znaczeń aspektowych, każde $\mathrm{z}$ nich rozpatrywane było oddzielnie, $\mathrm{w}$ części poświęconej odpowiedniej kategorii aspektowej. Ponieważ niekiedy niemożliwe jest zaprezentowanie wyłącznie aktualnie rozważanej części zdania złożonego bez utraty jego znaczenia, w przedstawionych poniżej przykładach polskich zdań złożonych, których zdania składowe niosą różne znaczenia aspektowe, kursywą zaznaczona zostanie aktualnie analizowana część zdania.

\subsection{Niemieckie odpowiedniki translatywne polskich fraz dokonanych}

W polskim tekście poddanym badaniu stwierdzono trzy zasadnicze sposoby wyrażania dokonanego znaczenia aspektowego. We wszystkich zdaniach na znaczenie dokonane wskazywała forma czasownika w funkcji orzeczenia, której towarzyszyły dodatkowe indykatory dokonaności. Owymi nieczasownikowymi nośnikami dokonaności $\mathrm{w}$ zdaniach polskich były formy rzeczownika $\mathrm{w}$ funkcji dopełnienia, okoliczniki oraz spójniki zdania okolicznikowego czasu w połączeniu $\mathrm{z}$ okolicznikami.

\section{język polski}

1. forma czasownika + forma rzeczownika $\mathrm{w}$ funkcji dopełnienia (+ okolicznik)

2. forma czasownika + okolicznik

3. forma czasownika + spójnik zdania okolicznikowego czasu + okolicznik

\section{język niemiecki}

a. forma rzeczownika w funkcji dopełnienia

b. forma rzeczownika w funkcji dopełnienia + forma czasownika (+ okolicznik)

a. ustalona syntagma

b. okolicznik

c. spójnik zdania okolicznikowego czasu + okolicznik

a. spójnik zdania okolicznikowego czasu + okolicznik 


\section{Forma czasownika + forma rzeczownika w funkcji dopelnienia (+ okolicznik ${ }^{8}$ )}

$\mathrm{O}$ ile forma polskiego czasownika jest powszechnie uznawanym nośnikiem znaczenia aspektowego, o tyle forma rzeczownika w funkcji dopełnienia jako indykator dokonaności może budzić pewne kontrowersje. Wnioski dotyczące formy rzeczownika w funkcji dopełnienia jako wskaźnika znaczenia aspektowego zdania zostały sformułowane m.in. przez Verkuyla (1999). Na podstawie obserwacji słowiańskich zdań dokonanych i niedokonanych badacz ten stwierdził, iż słowiański czasownik dokonany wymaga obecności w zdaniu dopełnienia bliższego w postaci frazy rzeczownikowej zawierającej informację o liczebności zbioru stanowiącego argument.

Na podstawie wniosków sformułowanych przez Verkuyla, jak również w oparciu o własne spostrzeżenia, dotyczące ukonkretniającego znaczenia aspektu dokonanego, do potencjalnych indykatorów znaczenia dokonanego w języku polskim zaliczono rzeczowniki, których desygnaty mogą zostać zidentyfikowane przez nadawcę i odbiorcę w określonej sytuacji komunikacyjnej. Poprzez ukonkretnienie dopełnienia zdania ukonkretnieniu ulega cała relacjonowana w zdaniu sytuacja. W ten sposób rzeczowniki te czynią referowaną sytuację wyjątkową, jednostkową.

Owe rzeczownikowe nośniki dokonaności występują najczęściej w liczbie pojedynczej. Indywidualność ich signifikatów uzyskiwana jest zazwyczaj poprzez dołączenie do rzeczownika zaimka wskazującego lub dzierżawczego. Ponadto zaliczono tu rzeczowniki w liczbie mnogiej, którym znaczenie określoności przydają zaimki nieokreślone wprowadzające znaczenie całej klasy przedmiotów (np. wszystkie).

Należy jednak zauważyć, iż forma rzeczownika w funkcji dopełnienia może być nośnikiem znaczenia dokonanego, o ile inne elementy zdaniowe nie wprowadzają znaczenia iteratywności, np. pojawienie się okolicznika iteratywizującego w przytoczonym poniżej przykładzie zmieniłoby znaczenie aspektowe zdania na niedokonane (por. Norbert Wiener zaczą swoja autobiografie od stów I was a child prodigy, bytem cudownym dzieckiem. - Norbert Wiener wielokrotnie zaczynat swoja autobiografie, lecz nigdy jej nie skończyt).

W poddanych badaniu zdaniach niemieckich odpowiednikami stanowiącego indykator dokonaności w języku polskim połączenia formy czasownika i formy rzeczownika w funkcji dopełnienia były:

\section{a. Forma rzeczownika w funkcji dopelnienia}

Podobnie jak w języku polskim, tak i w języku niemieckim za potencjalne nośniki dokonaności uznane zostały rzeczowniki, których desygnaty mogą zostać zidentyfikowane przez nadawcę i odbiorcę w określonej sytuacji komunikacyjnej. Rzeczowniki takie pośrednio dookreślają i czynią jednostkową całą referowaną w zdaniu sytuację poprzez ukonkretnienie dopełnienia zdania. Jak wspomniano, zazwyczaj są to rzeczowniki w liczbie pojedynczej, o indywidualnym signifikatum. W języku niemieckim jego indywidualność uzyskiwana jest najczęściej bądź poprzez dołączenie do rzeczownika rodzajnika określonego, zaimka wskazującego lub dzierżawczego, bądź poprzez towarzyszące rzeczownikowi przydawki, np. w formie liczebników porządkowych lub przymiotników w stopniu najwyższym.

Norbert Wiener zaczạ $\underline{\underline{\text { swoja }} \text { autobiografie }}$ od słów I was a child prodigy, byłem cudownym dzieckiem [...] (44)
Norbert Wiener begann seine Biographie mit den Worten I was a child prodigy - ich war ein Wunderkind [...] (37)

\section{b. Forma rzeczownika w funkcji dopelnienia ${ }^{9}+$ forma czasownika $\left(+\right.$ okolicznik $\left.^{10}\right)$}

Jak wspomniano wyżej, za potencjalne nośniki znaczenia dokonanego w języku niemieckim uznane zostały formy czasów gramatycznych Plusquamperfekt oraz Perfekt użyte w znaczeniu rezultatywnym, które tworzone są jedynie od czasowników transformatywnych. Ponieważ jednak o rezultatywnym (dokonanym) znaczeniu formy czasu Plusquamperfekt i Perfekt nie można wnioskować na podstawie samej obecności w zdaniu czasownika transformatywnego, konieczne

\footnotetext{
${ }^{8}$ Por. niżej.

${ }^{9}$ Por. wyżej.

${ }^{10}$ Por. niżej.
} 
jest odwołanie się do kontekstu, w jakim dane zdanie się pojawiło. Stąd formy czasu Plusquamperfekt lub Perfekt stanowić mogą jedynie niesamodzielne indykatory dokonaności.

W każdym razie dała rezultaty, ponieważ przestudiowałem w końcu ową książkę od deski do deski i zbudowałem maszynę Wimshursta oraz induktor Ruhmkorffa. (174)
Jedenfalls zeigte sie Ergebnisse, denn

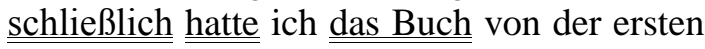
bis zur letzten Seite durchstudiert und eine Wimshurstmaschine sowie einen Ruhmkorffinduktor gebaut. (135)

\section{Forma czasownika + okolicznik}

Obecne w polskich zdaniach okolicznikowe nośniki dokonaności zostały podzielone na kilka grup znaczeniowych. Wyróżnione zostały:

a. Okoliczniki wprowadzające znaczenie momentalności akcji, np. naraz, niespodziewanie, wtem, nagle

Nadanie relacjonowanej czynności cechy momentalności powoduje, że jest ona postrzegana $\mathrm{z}$ perspektywy zewnętrznej, jako niepodzielna całość. $Z$ uwagi na interakcje pomiędzy znaczeniami aspektowymi i akcjonalnymi należy podkreślić, iż momentalność związana jest z dokonanością jedynie wtedy, gdy inne elementy zdaniowe nie wprowadzają znaczenia iteratywności. Nie budzi wszak wątpliwości poprawność zdania Zazwyczaj nagle odstanial swa prawdziwa naturę, co więcej - niemożliwe jest tu użycie czasownika dokonanego *Zazwyczaj nagle odstonit swa prawdziwa naturę. Stąd w przypadku zdań zawierających okoliczniki wprowadzające znaczenie momentalności akcji należy uwzględnić dodatkowe wskaźniki znaczenia aspektowego, zwłaszcza zaś kontekst, w jakim dane zdanie się pojawiło.,

b. Okoliczniki wprowadzające znaczenie semelfaktywności, np. po raz pierwszy, 26 lipca 1944 roku, raz

Znaczenie semelfaktywne jest wprawdzie $\mathrm{z}$ reguły charakteryzowane jako związane $\mathrm{z}$ dokonanością (por. m.in. Czochralski 1975), lecz sama obecność w polskim zdaniu okoliczników wskazujących na jednokrotność zdarzenia nie przesądza o jego znaczeniu dokonanym. W przypadku okoliczników wprowadzających znaczenie semelfaktywne decydujące znaczenie ma bowiem momentalne bądź duratywne ujęcie czynności. Połączenie semelfaktywności $\mathrm{z}$ momentalnością skutkuje bowiem dokonanym znaczeniem zdania (np. W 1944 roku rozpoczałem nauke $w$ szkole średniej), natomiast połączenie semelfaktywności z duratywnością - znaczeniem niedokonanym (np. Po raz pierwszy jechatem wówczas konno).,

c. Okoliczniki wprowadzające znaczenie bezpośredniego następowania po sobie zdarzeń, np. zaraz potem, za moment, po chwili, chwile po ..., zaraz po...

$\mathrm{W}$ polskich zdaniach określających wzajemne stosunki czasowe między akcjami na zasadzie uprzedniość - następczość często (przynajmniej) czynność późniejsza ujmowana jest jako momentalna, tj. dokonana, np. Po chwili wrócit. Jednak dzieje się tak jedynie wówczas, gdy inne elementy zdaniowe nie wprowadzają znaczenia iteratywności, np. Codziennie wracat do domu zaraz po pracy.,

d. Okoliczniki wskazujące na zupełność czynności ${ }^{11}$, np. całkowicie, bez reszty, kompletnie Znaczenie wyczerpania się czynności jest $\mathrm{w}$ języku polskim $\mathrm{z}$ reguły realizowane wraz $\mathrm{z}$ dokonanością, np. Kompletnie się dla ciebie poświęciłem, jednak pod warunkiem, że inne elementy zdaniowe nie wprowadzają znaczenia iteratywności bądź duratywności akcji. Można sobie bowiem wyobrazić czynność wyczerpującą się wielokrotnie, np. Za każdym razem doszczętnie pozbawiat mnie złudzeń, lub wyczerpującą się przez długi czas, np. Przez cate życie bez reszty poświęcałem się pracy.

Odpowiednikami stanowiącego indykator dokonaności w języku polskim połączenia formy czasownika i okolicznika były ustalone syntagmy, okoliczniki oraz spójnik zdania okolicznikowego czasu als $\mathrm{w}$ połączeniu $\mathrm{z}$ okolicznikiem. Ponieważ okoliczniki obecne $\mathrm{w}$

\footnotetext{
${ }^{11}$ Zupełność czynności rozumiana jest jako osiagnnięcie wewnętrznej granicy akcji, po której czynność nie może być kontynuowana, ponieważ się wyczerpała.
} 
zdaniach niemieckich stanowiły pełnoleksykalne odpowiedniki okoliczników występujących w tekście oryginalnym, przy równoczesnym braku elementów językowych wprowadzających znaczenia akcjonalne powodujące zmianę znaczenia aspektowego zdania ${ }^{12}$, zostały one uznane za indykatory znaczenia dokonanego.

\section{a. Ustalona syntagma}

$\mathrm{Za}$ ustaloną syntagmę pozwalającą wnioskować o dokonanym znaczeniu aspektowym niemieckiego zdania została uznana struktura 'bleiben + bezokolicznik czasownika określającego pozycję lub lokalizację'. Konstrukcja ta wprawdzie zazwyczaj niesie znaczenie duratywności (niedokonaności), jednak - jak pisze Fabricius-Hansen - może być również operatorem ingresywności pod warunkiem, że: ,[...] die im aktuellen Satz beschriebene P-Phase ${ }^{13}$ keine Fortsetzung [...] darstellt, sondern links an eine kontextuell gegebene $\sim$ P-Phase grenzt" (FabriciusHansen 2004: 95). Należy jednak zauważyć, że ingresywne znaczenie niesione przez tę strukturę W zdaniu niemieckim nie musi oznaczać znaczenia dokonanego jego polskiego odpowiednika. Ingresywność jest bowiem związana z dokonanością pod warunkiem, że inne elementy zdaniowe lub kontekst nie wnoszą znaczenia iteratywności bądź duratywności. Stąd dla jednoznacznego określenia znaczenia aspektowego zdań zawierających tę strukturę konieczne jest uwzględnienie innych nośników znaczenia aspektowego, zwłaszcza zaś kontekstu, w jakim dane zdanie się pojawiło.

Ponieważ czytałem absolutnie wszystko, co wpadło w rękę, ujrzawszy, że Janek i Jeremi obnoszą się z tomami o niezłych tytułach, jak „W cieniu zakwitających dziewcząt”, zaraz sobie pożyczytem pierwszy tom cyklu $i$ ugrzaztem już na wstęnych kartkach. (104)
Da ich absolut alles las, was mir in die Hände fiel, und sah, wie Janek und Jeremi sich mit Bänden herumtrugen, die gar keine so üblen Titel hatten, wie zum Beispiel „Im Schatten erblühender Mädchen", lieh ich mir gleich den ersten Band des Zyklus aus, $\underline{\underline{\text { blieb }}}$ aber schon auf den ersten Seiten stecken. (82)

\section{b. Okoliczniki}

Jak wspomniano, przedstawione poniżej niemieckie okoliczniki zostały uznane za potencjalne nośniki znaczenia dokonanego, jako że stanowiły pełnoleksykalne odpowiedniki okoliczników występujących $\mathrm{w}$ tekście oryginalnym, przy równoczesnym braku elementów językowych wprowadzających znaczenia akcjonalne, zmieniające znaczenie aspektowe odnośnego zdania. Podobnie jak okoliczniki obecne w polskim tekście, zostały one podzielone na cztery grupy znaczeniowe:

- Okoliczniki wyrażające momentalność akcji: plötzlich, jählings, sofort, auf der Stelle, im $\mathrm{Nu}$

Podobnie jak polskie, tak i niemieckie okoliczniki wyrażające momentalność akcji mogą zostać uznane za nośniki dokonaności, o ile inne elementy zdaniowe lub kontekst nie wprowadzają znaczenia iteratywności.

W pewnej chwili zwiało chmurę na tercjana, z której wynurzył się, płacząc jak bóbr. (198)
Plötzlich wehte der Wind die ganze Wolke auf den Pedell, der bitterlich weinend daraus hervortauchte. (154)

\section{- Okoliczniki wskazujące na jednokrotność zdarzenia}

\footnotetext{
$12 \mathrm{Tj}$. znaczenie iteratywności w przypadku okoliczników wprowadzających znaczenie momentalności akcji, bezpośredniego następowania po sobie zdarzeń oraz zupełności czynności, znaczenie duratywności natomiast w przypadku okoliczników wprowadzających znaczenie semelfaktywności oraz zupełności czynności.

${ }^{13}$ W koncepcji Fabricius-Hansen (2004) 'P-Phase' oznacza interwał czasowy, w którym zachodzi stan lub trwa proces P. Oznaczenie ' P-Phase' natomiast odnosi się do interwału czasowego, w którym proces lub stan P nie zachodzi.
} 
Analogicznie do swych polskich odpowiedników niemieckie okoliczniki semelfaktywizujące mogą zostać uznane za nośniki dokonaności pod warunkiem, że inne elementy zdaniowe lub kontekst nie wprowadzają znaczenia duratywności. Wśród niemieckich okoliczników semelfaktywizujących wyróżniono okoliczniki explicite wskazujące na jednostkowość i niepowtarzalność relacjonowanej w zdaniu sytuacji, typu einmal, zum ersten Mal, ein einziges Mal, oraz okoliczniki semelfaktywizujące poprzez 'lokalizację zdarzenia w czasie'.

- einmal / zum ersten Mal / ein einziges Mal

Raz jeden wyruszyliśmy $\mathrm{z}$ nimi na miasto $\mathrm{w}$ okolicznościach nadzwyczajnych i zgoła szczególnych. (202)

Ein einziges Mal marschierten wir damit durch die Stadt, aus einem außergewöhnlichen, ganz und gar besonderen Anlass. (156)

- Okoliczniki lokalizujące wydarzenie w czasie, np. ein Jahr vor meinem Abitur, am frühen Morgen, in zwei Jahren.

[...] skoro się to wystawia, skoro sa widzowie i nabywcy i krytycy-apologeci, $\underline{\underline{z a}}$ lat kilkanaście sprawa spetryfikuje się $\mathrm{w}$ podręcznikach historii sztuki jako okres już miniony, nieodwracalny. (186)
[...] Wenn man das ausstellt, wenn es Betrachter und Käufer und auch apologetische Kritiker gibt, wird sich die Angelegenheit in einem Dutzend Jahren in den Nachschlagewerken der Kunstgeschichte als eine bereits unwiderruflich vergangene Periode petrifizieren. (144)

\section{- Okoliczniki wyrażające bezpośrednie następowanie po sobie zdarzeń: bald, gleich}

Podobnie jak polskie, tak i niemieckie okoliczniki wyrażające bezpośrednie następowanie po sobie zdarzeń mogą zostać uznane za nośniki dokonaności, o ile inne elementy zdaniowe lub kontekst nie wprowadzają znaczenia iteratywności.

To, że w ogóle mogłem robić tak wiele (a pokaże się za chwile, że istotnie mnóstwo miałem pracochłonnej roboty), zdumiewa mnie dziś, gdy doprawdy na nic omal nie starcza czasu. (143)

Ale przekonałem się wnet, że piękne, lśniące lusterkami są tylko kasztany na wolności [...] (39)
Der Umstand, dass ich überhaupt soviel tun konnte (und es wird sich gleich herausstellen, dass ich tatsächlich eine Menge intensiver Arbeit zu bewältigen hatte), verwundert mich heute, da mir die Zeit beinahe zu nichts mehr reicht. (112)

Aber ich überzeugte mich bald, dass die Kastanien nur im Freien schön waren und wie Spiegel glänzten [...] (33)

\section{- Okoliczniki wskazujące na wyczerpanie się czynności: vollends, restlos}

Analogicznie do swych polskich odpowiedników niemieckie okoliczniki wskazujące na wyczerpanie się czynności mogą zostać uznane za nośniki dokonaności pod warunkiem, że inne elementy zdaniowe lub kontekst nie wprowadzają znaczenia duratywności bądź iteratywności.

Podczas drogi do Lwowa przysiadł się do mnie jeden $\mathrm{z}$ wykładowców, podchorąży, któremu byłem wprost niesłychanie sympatyczny, więcej: który wręcz podziwiał mnie; serdeczność, ba, uznanie (nie wiadomo całkiem za co), okazywane przez prawie oficera, zupełnie mnie otumaniło. (207)
Während der Fahrt nach Lwów hatte sich einer der Ausbilder, ein Fähnrich, zu mir gesetzt, dem ich unerhört sympathisch vorkam, mehr noch, der mich geradezu bewunderte; die Herzlichkeit, ach was, die Anerkennung (ich wusste gar nicht wofür), die mir der Quasioffizier bezeugte, betörte mich vollends. (160) 


\section{c. Spójnik zdania okolicznikowego czasu als + okolicznik $^{14}$}

Zdanie okolicznikowe czasu ze spójnikiem czasowym als charakteryzowane jest jako wyrażające sytuację jednokrotną, mającą miejsce $\mathrm{w}$ przeszłości, tj. jako zdanie o znaczeniu semelfaktywnym (por. Helbig, Buscha 2001: 601). Jak wspomniano, w przypadku semelfaktywności decydującym dla znaczenia aspektowego zdania jest momentalne bądź duratywne ujęcie czynności. Stąd dla jednoznacznego określenia znaczenia aspektowego zdania zawierającego spójnik czasowy als konieczne jest uwzględnienie kontekstu, w jakim dane zdanie wystąiło.

Pamiętam pierwsze wtajemniczenia w sztukę samochodowa, kiedy na rok przed matura dostałem się pod władzę milkliwego instruktora, wyglądającego, jakby żywił się wyłącznie czarnym olejem. (131)
Ich erinnere mich noch der ersten Unterweisung in der Automobilkunst, $\underline{\underline{\text { als }}}$ ich ein Jahr vor meinem Abitur unter die Fuchtel eines schweigsamen Ausbilders geriet, der ganz so aussah, als ob er sich ausschließlich von schwarzem Öl ernährte. (102-103)

\section{Forma czasownika + spójnik zdania okolicznikowego czasu zanim, jak tylko, póki + okolicznik $^{15}$}

Do potencjalnych indykatorów dokonaności w języku polskim zostały zaliczone spójniki zdania okolicznikowego czasu zanim, jak tylko oraz póki. Spójniki zanim oraz jak tylko należą do środków językowych wprowadzających znaczenie bezpośredniego następowania po sobie zdarzeń. W języku polskim czynność wyrażana przez zdanie podrzędne wprowadzane przez spójnik zanim lub jak tylko zazwyczaj przedstawiana jest jako akcja momentalna, a wskutek tego - dokonana, np. Zanim wyjde, posprzątam. Jednak dzieje się tak jedynie wówczas, gdy inne elementy zdaniowe nie wprowadzają znaczenia iteratywności, np. Jak tylko znikatem za rogiem, robotnicy odkładali narzędzia. Stąd dla jednoznacznego ustalenia znaczenia aspektowego zdań zawierających spójnik wyrażający następowanie po sobie dwóch czynności należy uwzględnić dodatkowe wskaźniki znaczenia aspektowego, zwłaszcza zaś kontekst, w jakim dane zdanie się pojawiło.

Z kolei zdanie okolicznikowe czasu zawierające spójnik póki charakteryzowane jest jako wyrażające moment zakończenia czynności nazywanej czasownikiem terminatywnym, co - jak wskazuje Andersson (2004: 7) - jest równoznaczne z jej wyczerpaniem (zupełnością). Należy jednak zauważyć, że - podobnie jak okoliczniki wprowadzające znaczenie wyczerpania się czynności - spójnik czasowy póki może być indykatorem dokonaności jedynie wówczas, gdy inne elementy zdaniowe lub kontekst nie wnoszą znaczenia iteratywności bądź duratywności akcji.

Za potencjalne indykatory znaczenia dokonanego w zdaniach niemieckich zostały uznane spójniki zdania okolicznikowego czasu ehe / bevor oraz bis, stanowiące pełnoleksykalne odpowiedniki spójników występujących w tekście oryginalnym, przy równoczesnym braku elementów językowych wprowadzających znaczenia akcjonalne powodujące zmianę znaczenia aspektowego zdania.

Zanim zdażyłem pobiec na ganek, aby przekonać się, co się stało z kulką, do pokoju wpadła matka, a za nią ojciec, którego strzał wywabił $\mathrm{z}$ ordynacji, przybiegł więc $\mathrm{w}$ białym płaszczu i z laryngologicznym lustrem na czole. (99)
Bevor ich auf den Gang laufen konnte, um festzustellen, was mit der Kugel geschehen war, stürzte meine Mutter ins Zimmer und hinter ihr mein Vater, den der Schuss aus dem Behandlungsraum herausgelockt hatte; er kam in seinem weißen Kittel und mit dem laryngologischen Spiegel auf der Stirn angerannt. (79)

\footnotetext{
${ }^{14}$ Por. wyżej.

${ }^{15}$ Por. wyżej.
} 
Dziwne się wtedy wycinało i kleiło rzeczy, bo oprócz zwyczajnych czołgów i samolotów, także maski gazowe, które można było nawet nosić, póki od śliny $i$ oddychania przez dziurkowane denko papierowego pochtaniacza dokumentnie sie nie porozklejaty. (135-136)
Es wurden damals seltsame Dinge ausgeschnitten und geklebt, außer den gewöhnlichen Panzern und Flugzeugen auch Gasmasken, die man sogar tragen konnte, so lange, $\underline{\underline{b i s}}$ sie vom Speichel und vom Atmen durch den löchrigen Boden des papiernen Einsatzes restlos aus dem Leim gingen. (106)

\subsection{Niemieckie odpowiedniki translatywne polskich fraz niedokonanych}

W polskim tekście poddanym badaniu stwierdzono pięć zasadniczych sposobów wyrażania niedokonanego znaczenia aspektowego. We wszystkich zdaniach na znaczenie niedokonane wskazywała forma czasownika w funkcji orzeczenia. W czterech spośród pięciu typów zdań niedokonanych ${ }^{16}$ czasownikowemu nośnikowi niedokonaności towarzyszyły dodatkowe indykatory. Owymi dodatkowymi sygnifikatorami niedokonaności w zdaniach polskich były: forma rzeczownika w funkcji dopełnienia, spójnik zdania okolicznikowego czasu, spójnik zdania porównawczego oraz okolicznik.

\section{język polski}

1. forma czasownika + forma rzeczownika $w$ funkcji dopełnienia

2. forma czasownika + spójnik zdania porównawczego

3. forma czasownika + okolicznik

4. forma czasownika

\section{język niemiecki}

a. forma rzeczownika w funkcji dopełnienia

a. spójnik zdania porównawczego
a. ustalona syntagma (+ okolicznik)
b. okolicznik
c. prefiks czasownikowy
d. konstrukcja duratywizująca + okolicznik

5. forma czasownika + spójnik zdania a. spójnik zdania okolicznikowego czasu okolicznikowego czasu

\section{Forma czasownika + forma rzeczownika $w$ funkcji dopelnienia}

Podobnie jak w przypadku polskich zdań dokonanych, tak i tutaj forma rzeczownika w funkcji dopełnienia została uznana za potencjalny wskaźnik znaczenia aspektowego zdania w oparciu o wnioski sformułowane przez Verkuyla (1999). Do rzeczownikowych indykatorów znaczenia niedokonanego $\mathrm{w}$ języku polskim zaliczone zostały rzeczowniki o nieokreślonych desygnatach, które nie mogą zostać jednoznacznie zidentyfikowane przez odbiorcę w kontekście dyskursu. Owe rzeczownikowe nośniki niedokonaności występują najczęściej w liczbie mnogiej. Nieokreśloność ich signifikatów uzyskiwana jest zazwyczaj poprzez dołączenie do rzeczownika przydawek (w postaci zaimków lub przymiotników) niosących znaczenie wielości desygnatów, np. niektóre, wiele, różne, rozmaite. Rzeczowniki te, wskazując na wiele przedmiotów podlegających czynności (wiele dopełnień), często wskazują równocześnie na powtarzanie się zdarzenia i tym samym nadają

${ }^{16}$ Ze względu na sposób wyrażania znaczenia niedokonanego. 
zdaniu znaczenie iteratywności, a wskutek tego - zazwyczaj - niedokonaności ${ }^{17}$. Jednak z uwagi na fakt, iż rzeczowniki wskazujące na wielość przedmiotów potencjalnie nimi nazywanych mogą również wystapić w odniesieniu do sytuacji jednorazowej, która wprawdzie podzielona jest na wewnętrzne akty, lecz w zdaniu ujmowana jest jako całość, z perspektywy zewnętrznej, tj. ponieważ sama forma rzeczownika $\mathrm{w}$ funkcji dopełnienia nie decyduje o aspekcie niedokonanym zdania polskiego, należy uznać ją za indykator niesamodzielny. Najczęściej głównym wyznacznikiem znaczenia aspektowego takich zdań jest kontekst zdaniowy i sytuacyjny.

We wszystkich niemieckich zdaniach, w których polskich odpowiednikach indykatorem niedokonaności było połączenie formy czasownika i formy rzeczownika w funkcji dopełnienia, wystapiła potencjalnie wskazująca na znaczenie niedokonane forma rzeczownika $\mathrm{w}$ funkcji dopełnienia. Podobnie jak w języku polskim, tak i w języku niemieckim za potencjalne nośniki niedokonaności uznane zostały rzeczowniki, których desygnaty nie mogą zostać jednoznacznie zidentyfikowane przez odbiorcę w określonej sytuacji komunikacyjnej. Należą tu rzeczowniki w liczbie mnogiej, występujące z rodzajnikiem zerowym bądź przydawkami (w postaci zaimków lub przymiotników) niosącymi znaczenie wielości desygnatów określonego rzeczownika $\mathrm{w}$ danym kontekście, np. manche, einige, mehrere, viele, verschiedene.

$\underline{\underline{\text { Wyszukiwałem już wtedy sobie rozmaite }} \text { Nunmehr suchte ich mir verschiedene }}$ preteksty. (38)

Ausflüchte aus. (32)

\section{Forma czasownika + spójnik zdania porównawczego im ... tym ...}

Do potencjalnych indykatorów niedokonaności w języku polskim został zaliczony spójnik zdania porównawczego im ... tym ..., występujący w zdaniach o znaczeniu przeszłym ${ }^{18}$. Spójnik ten wyraża stopniowy rozwój w czasie czynności nazywanych czasownikami stanowiącymi orzeczenia zdań składowych. Jeśli zaś dana akcja ma być postrzegana jako stopniowo się rozwijająca, musi mieć ona charakter procesualny, duratywny, musi być postrzegana z perspektywy wewnętrznej, właśnie jako rozwijając a się w czasie, co w języku polskim wyrażane jest przez aspekt niedokonany. Stąd spójnik zdania porównawczego w zdaniach o znaczeniu przeszłym uznany został za nośnik niedokonaności.

W niemieckich odpowiednikach polskich zdań niedokonanych, w których indykator znaczenia aspektowego stanowiło połączenie formy czasownika i spójnika zdania porównawczego, za potencjalny nośnik znaczenia niedokonanego także uznany został spójnik zdania porównawczego, mianowicie je ... desto / je ... umso. Helbig i Buscha charakteryzują znaczenie zdania porównawczego ze spójnikiem złożonym je ... desto / je ... umso w następujący sposób: „Im Proportionalsatz mit der getrennt-mehrteiligen Subjunktion je...desto / umso besteht das Entsprechungsverhältnis zwischen dem in der Entwicklung gesehenen Grad (Qualität) des HSGeschehens ${ }^{19}$ [...] und einem entsprechenden Grad (Qualität) des NS-Geschehens" (Helbig, Buscha 2001: 606). Jak wspomniano, jeśli stopień (jakość) zdarzeń, o których mowa w zdaniu głównym i pobocznym, postrzegany jest jako rozwijający się w czasie, same zdarzenia muszą być postrzegane z perspektywy wewnętrznej, co wyrażane jest przez aspekt niedokonany.

$\underline{\underline{I m}}$ więcej się bałem, tym bardziej mi się podobało i na odwrót $[\ldots]$ (127)

$\underline{\underline{\mathrm{Je}}}$ mehr ich mich fürchtete, $\underline{\underline{\text { um so }}}$ besser gefiel es mir, und umgekehrt [...] (100)

\section{Forma czasownika + okolicznik}

Obecne w polskich zdaniach okolicznikowe nośniki niedokonaności zostały podzielone na kilka grup znaczeniowych, mianowicie:

a. Okoliczniki iteratywizujące, np. czasem, dwa razy, wieczorami, wielokrotnie itd.

\footnotetext{
${ }^{17}$ Należy zauważyć, że komponent znaczeniowy iteratywności jest zawarty również m.in. w znaczeniu czasowników dystrybutywnych, które w języku polskim są czasownikami dokonanymi, np. powyrzucać, pozapisywać.

${ }^{18} \mathrm{~W}$ zdaniach o znaczeniu przyszłym spójnik porównawczy może wprowadzać znaczenie dokonane, np. Im szybciej to zrobię, tym szybciej pójdę do domu.

${ }^{19}$ Skrót 'HS' oznacza zdanie główne (Hauptsatz), skrót 'NS' natomiast - zdanie poboczne (Nebensatz).
} 
Znaczenie iteratywne $\mathrm{w}$ języku polskim jest wprawdzie $\mathrm{z}$ reguły związane $\mathrm{z}$ niedokonanością, lecz sama obecność w zdaniu okoliczników iteratywizujących nie przesądza o jego znaczeniu niedokonanym. Wprawdzie część z ww. okoliczników nie wykazuje łączliwości z czasownikami dokonanymi, np. okoliczniki wprowadzające znaczenie habitualności ${ }^{20}$, okoliczniki zawsze, zwykle, co chwila $\mathrm{i}$ in., w związku $\mathrm{z}$ czym moga one zostać uznane za samodzielne indykatory niedokonaności. Jednak część okoliczników iteratywizujących, np. czasami, za każdym razem, wielokrotnie, może występować w zdaniach dokonanych, o ile przedział czasowy, w którym dana czynność była powtarzana ujmowany jest z perspektywy zewnętrznej, jako zamknięty okres $\mathrm{w}$ przeszłości.,

b. Okoliczniki duratywizujące, np. dtugo, latami, przez pewien czas itd.

Okoliczniki te zostały zaliczone do indykatorów niedokonaności wskutek obserwacji, iż nadanie czynności cechy duratywności powoduje, że jest ona postrzegana z perspektywy wewnętrznej, jako rozwijająca się w czasie, co z kolei wyrażane jest poprzez aspekt niedokonany.,

c. Okoliczniki niosące znaczenie kontynuacji czynności, np. nadal, bez przerwy, wciaż itd.

Okoliczniki te zostały zaliczone do indykatorów niedokonaności wskutek spostrzeżenia, iż przedstawienie czynności jako kontynuowanej pociaga za sobą jej ujmowanie z perspektywy wewnętrznej, jako czynności trwającej, co wyrażane jest za pomocą aspektu niedokonanego.,

d. Okoliczniki wskazujące na równoczesność dwóch akcji, np. równocześnie, w tym samym czasie. W polskich zdaniach wyrażających równoczesność dwóch czynności (przynajmniej) akcja stanowiąca tło ujmowana jest z perspektywy wewnętrznej, jako proces, wskutek czego uzyskuje znaczenie niedokonane.

e. Okoliczniki wyrażające stopniowe narastanie pewnych jakości czynności, ich stopniowy rozwój, np. okolicznik złożony z przysłówka coraz i przysłówka w stopniu wyższym, np. coraz wyraźniej / bardziej itd. Mamy tu do czynienia z sytuacją analogiczną do zdania porównawczego ze spójnikiem złożonym im... tym.... Jeśli bowiem cecha czynności nazywana przysłówkiem ma być jakością narastającą w czasie, owo narastanie musi być postrzegane $\mathrm{z}$ perspektywy wewnętrznej, jako proces, co wyrażane jest za pomocą aspektu niedokonanego.

Odpowiednikami stanowiącego indykator niedokonaności w języku polskim połączenia formy czasownika i okolicznika były ustalone syntagmy, okoliczniki oraz konstrukcja duratywizująca w połączeniu z okolicznikiem. Ponieważ okoliczniki obecne w zdaniach niemieckich stanowiły pełnoleksykalne odpowiedniki okoliczników występujących w tekście oryginalnym, zostały one uznane za indykatory znaczenia niedokonanego.

\section{a. Ustalona syntagma (+ okolicznik ${ }^{21}$ )}

Za ustaloną syntagmę pozwalającą wnioskować o niedokonanym znaczeniu polskiego odpowiednika zdania niemieckiego została uznana konstrukcja überall, wo das nur ging. Oznaczając wielość miejsc, w jakich dana czynność była (lub będzie) wykonywana, struktura ta może równocześnie wskazywać na powtarzanie się czynności i tym samym nadawać zdaniu znaczenie iteratywności, a wskutek tego - zazwyczaj - niedokonaności. Jednak konstrukcja überall, wo das nur ging może również wystąpić w odniesieniu do sytuacji jednorazowej. Wówczas struktura ta wskazuje wprawdzie na wielość miejsc wykonywania czynności, lecz czynności jednorazowej, ujmowanej w zdaniu jako całość, z perspektywy zewnętrznej, co w języku polskim wyrażane jest za pomocą dokonanych czasowników dystrybutywnych. W przytoczonym poniżej zdaniu konstrukcja überall, wo das nur ging stanowi nośnik znaczenia niedokonanego, ponieważ mamy tu do czynienia $\mathrm{z}$ habitualnością całej sytuacji.

\footnotetext{
${ }^{20} \mathrm{~W}$ niniejszej pracy habitualność rozumiana jest jako typ iteratywności, tj. jako znaczenie czynności wykonywanych jako nawyki.

${ }^{21}$ Por. niżej.
} 
Przez czas pewien dosyć chętnie wieszałem się, gdzie się dało, gromadząc odpowiednie postronki, na niby oczywista i nie do końca, a także troszkę się samoudręczałem. (55)
Eine Zeitlang „erhängte“ ich mich ziemlich gern, überall, wo das nur ging, und ich sammelte dazu die geeigneten Stricke, alles in scheinbarem Ernst, doch eben nicht vollends, und ich pflegte mich auch ein wenig zu martern. (46)

\section{b. Okoliczniki}

Jak wspomniano, przedstawione poniżej niemieckie okoliczniki zostały uznane za potencjalne nośniki znaczenia niedokonanego, jako że stanowiły pełnoleksykalne odpowiedniki okoliczników występujących w tekście oryginalnym. Podobnie jak okoliczniki polskie, tak i okoliczniki niemieckie zostały podzielone na kilka grup znaczeniowych:

\section{- Okoliczniki iteratywizujące}

Do okoliczników iteratywizujących zostały zaliczone okoliczniki wskazujące, iż zdarzenie, o którym mowa, było (lub będzie) zdarzeniem wielokrotnie się powtarzającym. W ten sposób okoliczniki te nadają zdaniu znaczenie iteratywności, które $\mathrm{w}$ języku polskim jest $\mathrm{z}$ reguły związane $\mathrm{z}$ niedokonanością. Jednak sama obecność w niemieckim zdaniu okoliczników wskazujących na wielokrotność zdarzenia nie przesądza o niedokonanym znaczeniu jego polskiego odpowiednika. Z uwagi na brak łączliwości części polskich okoliczników iteratywizujących $\mathrm{z}$ czasownikami dokonanymi, ich niemieckie odpowiedniki mogą zostać uznane za samodzielne indykatory niedokonaności, np. okoliczniki wprowadzające znaczenie habitualności (abends, in den kühlen Tagen des heiteren Herbstes, in den Naturkundestunden, täglich, einmal in der Woche), okoliczniki immer, gewöhnlich, oft, alle Augenblicke i in., np.

$\mathrm{Na}$ wagary, wyznam z niejakim wstydem, nie śmiałem chodzić, niemniej, wypadały nieraz lekcje, i w takie godziny chodziło się na pobliski Wysoki Zamek, na Kortumowa Górę, na Kaiserwald [...] (108)
Die Schule wagte ich nicht zu schwänzen, was ich mit einer gewissen Scham bekenne, aber manchmal fiel der Unterricht aus, und in solchen Stunden ging man gewöhnlich zum nahe gelegenen Schloss, auf dem Kortumberg, in den Kaiserwald [...] (85)

Jednak część okoliczników iteratywizujących, np. manchmal, mehrmals, mehrfach, einige / unzählige / mehrere Male, jedes Mal i in., może występować w niemieckich odpowiednikach polskich zdań dokonanych, jeśli przedział czasowy, w którym dana czynność była (lub będzie) powtarzana ujmowany jest z perspektywy zewnętrznej, jako zamknięty okres.

W samej rzeczy „Czas nieutracony” zaczynatem od dzieciństwa bohatera, i te część wstępna ksiażki, która wielokrotnie przepisywatem $i$ opracowywatem, w końcu zdecydowałem się w całości odrzucić. (79)
In der Tat hatte ich die „Irrungen des Dr. Stefan T." mit der Kindheit des Helden begonnen, und diesen einleitenden Teil des Buches, den ich mehrfach umgeschrieben und bearbeitet hatte, beschloss ich letztlich in seiner Gesamtheit wegzulassen. (63-64)

Zatem dla jednoznacznego określenia znaczenia aspektowego zdania zawierającego okolicznik iteratywizujący konieczna jest obecność indykatorów wspomagających, np. innych okoliczników, czasowników o określonym znaczeniu, rzeczowników w funkcji dopełnienia w określonej formie itd. Najczęściej głównym wyznacznikiem ich znaczenia aspektowego jest kontekst zdaniowy i sytuacyjny.

- Okoliczniki duratywizujące: lange, lange/ längere Zeit, seit Jahren, Jahre hindurch i in.

Zostały tu zaliczone okoliczniki oznaczające długi przedział czasowy, w którym dana sytuacja powtarzała się lub będzie się powtarzać, oraz okoliczniki oznaczające znaczną rozciagłość czasową zdarzenia jednokrotnego, wskutek czego jest ono postrzegane z perspektywy wewnętrznej, jako proces. 
Wyznam, czego nigdy dotąd nie zrobiłem, $\dot{z} e$ oba lokowatem bardzo dlugo $w$ przestrzeni. (40)
Ich gestehe, was ich bisher noch nie getan habe, dass ich beide sehr lange im Raum lokalisiert habe. (34)

\section{- Okoliczniki oznaczające kontynuację czynności: weiter(hin), ununterbrochen, ohne Unterbrechung i in.}

Podobnie jak polskie, tak i niemieckie okoliczniki wnoszące znaczenie kontynuacji czynności zostały zaliczone do indykatorów niedokonaności wskutek spostrzeżenia, iż przedstawienie czynności jako kontynuowanej pociąga za sobą jej ujmowanie jako procesu, tj. z perspektywy wewnętrznej.

\begin{abstract}
Miałem okrutny dość zwyczaj poszturchiwania ojca łokciem w kinie podczas scen co silniejszych, a już na wyliczonych filmach niepohamowanie thukłem go omal bez przerwy; zakazy nie skutkowały, było to silniejsze ode mnie. (127)
\end{abstract}

\begin{abstract}
Ich hatte die burschikose Gewohnheit, meinem Vater während der ungestümeren Szenen im Kino Rippenstöße mit dem Ellenbogen zu versetzen, und bei den oben genannten Filmen drosch ich ihn hemmungslos fast ohne Unterbrechung; Verbote fruchteten nichts, es war eben stärker als ich. (100)
\end{abstract}

\section{- Okoliczniki wyrażające równoczesność akcji: gleichzeitig, zur gleichen Zeit}

Podobnie jak polskie, tak i niemieckie okoliczniki wskazujące na równoczesność dwóch akcji zostały zaliczone do indykatorów niedokonaności wskutek spostrzeżenia, iż przedstawienie dwóch czynności jako odbywających się równocześnie pociaga za sobą ujmowanie (przynajmniej) akcji stanowiącej tło jako procesu, jako akcji trwającej.

Widzę, że czy chciałem, czy nie chciałem, wspominając, równocześnie to wspominane porządkowałem i to tak, by układało się $\mathrm{w}$ tropy, wskazujące dosyć wyraźnie w moją stronę, mnie dzisiejszego, tak zwanego literata $[\ldots](7)$
Ich sehe, dass ich, einerlei ob willentlich oder nicht, gleichzeitig auch das Erinnerte ordnete, und zwar so, dass es sich zu Spuren formte, die recht deutlich in meine Richtung wiesen, auf mich, den heutigen, den so genannten Literaten [...] (9)

\section{- Okoliczniki wyrażające stopniowe narastanie jakości czynności}

Do okoliczników wyrażających stopniowe narastanie jakości czynności zaliczony został okolicznik złożony 'immer + przysłówek w stopniu wyższym', który - zgodnie z Deutsches Universalwörterbuch - oznacza stopniowe, lecz ciagłe narastanie jakości nazywanej przysłówkiem (por. Drosdowski (Ed.) 1996: 754). Mamy tu zatem do czynienia z sytuacją analogiczną do zdania porównawczego ze spójnikiem złożonym je ... desto / je ... umso. Jeśli bowiem cecha czynności nazywana przysłówkiem ma być jakością narastającą w czasie, owo narastanie musi być postrzegane $\mathrm{z}$ perspektywy wewnętrznej, jako proces. Ponieważ $\mathrm{w}$ języku polskim funkcję taką pełni aspekt niedokonany, konstrukcja 'immer + przysłówek w stopniu wyższym' została uznana za samodzielny indykator niedokonaności.

Pisząc o moich profesorach, czułem, coraz wyraźniej, z rosnącym niezadowoleniem, że wpadam $\mathrm{w}$ koleinę, jedną $\mathrm{z}$ wielu, wyżłobionych przez pokolenia mniej lub bardziej profesjonalnych wspominaczy. (119)
Während ich über meine Lehrer schrieb, fühlte ich immer deutlicher, und zwar mit wachsender Unzufriedenheit, dass ich auf ein Gleis geriet, auf eines der vielen, die von Generationen mehr oder weniger professioneller Memoirenschreiber ausgefahren worden sind. (93) 


\section{c. Prefiksy czasownikowe herum- oraz umher- (+ okolicznik $\left.{ }^{22}\right)$}

Zgodnie z Deutsches Universalwörterbuch (Drosdowski (red.) 1996) prefiksy czasownikowe herum- oraz umher- wnoszą znaczenie ciągłego, nieustannego wykonywania czynności nazywanej czasownikiem prostym, co powoduje przydanie jej charakteru nawyku. Ponieważ zaś habitualność jest znaczeniem akcjonalnym trwale związanym z niedokonanością, ww. prefiksy czasownikowe zostały uznane za indykatory znaczenia niedokonanego.

Mnóstwo kręciło się handlarzy z grzebykami i lusterkami, czesto gesto słyszało sie dzwonienie szlifierzy wędrownych i wołanie „gaarnki lutować!", sporo krążyło Cyganekwróżbiarek czy zwykłych całkiem żebraków, którzy za jedyny towar mieli własną biedę. (126)
Eine Menge ambulanter Händler mit Kämmen und Spiegeln trieben sich herum, $\underline{\underline{\text { oft }}}$ konnte man das Klimpern der wandernden Scherenschleifer und den Ruf „Töpfe löten!“" vernehmen, viele weissagende Zigeunerinnen oder auch ganz gewöhnliche Bettler, die die eigene Not als einzige Ware hatten, liefen umher. (99)

\section{d. Konstrukcja duratywizująca + okolicznik ${ }^{23}$}

Za nośniki znaczenia duratywnego - a wskutek tego niedokonanego - w języku niemieckim uznane zostały połączenia 'czasownik + przyimek an + dopełnienie w celowniku' oraz 'imiesłów czasu przeszłego (Partizip II) + halten + okolicznik'. Na pierwszą z nich jako nośnik duratywności wskazują m.in. Krifka (1989) oraz Czarnecki (1998). Na drugą z kolei Czochralski (1975: 205). Ścisły związek duratywności $\mathrm{z}$ aspektem niedokonanym w języku polskim pozwolił uznać ww. konstrukcje za sygnifikatory znaczenia niedokonanego w języku niemieckim.

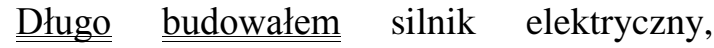
podobny zewnętrznie do starej parowej maszyny Watta $\mathrm{z}$ balansjerem [...] (172)

Twarz miałem pucołowata, oczy zwykle dość wytrzeszczone, bo $\mathrm{z}$ natury byłem ciekawy, a i gębę często rozdziawiałem, zdaje się, sądziłem, że dodaje mi to uroku. (65)
Längere Zeit baute ich an einem Elektromotor, der äußerlich der alten Dampfmaschine Watts mit einem Hebel glich [...] (134)

Mein Gesicht war pausbäckig, die Augen quollen gewöhnlich ziemlich weit hervor, denn ich war von Natur aus neugierig, und auch den Mund hielt ich oft geöffnet, anscheinend weil ich wähnte, dass mir das gut stand. (52)

\section{Forma czasownika}

Jak wspomniano, słowiański czasownik w formie osobowej jako nośnik znaczenia aspektowego nie budzi większych wątpliwości, w związku $\mathrm{z}$ czym nie będzie tu omawiany. W niemieckich odpowiednikach polskich zdań, w których jedyny indykator znaczenia niedokonanego stanowiła forma osobowa czasownika, jako potencjalne nośniki niedokonaności wystapiły: nagromadzenie czasowników bliskoznacznych, okolicznik stets / immer, spójniki zdania okolicznikowego czasu während i wenn oraz konstrukcje iteratywizujące.

\section{a. Nagromadzenie czasowników bliskoznacznych}

Na podstawie spostrzeżeń poczynionych przez Baudot (2004b: 171) nagromadzenie czasowników bliskoznacznych zostało uznane za środek przydający zdaniu znaczenie iteratywne, a wskutek tego - zazwyczaj - niedokonane. Niekiedy jednak samo nagromadzenie w zdaniu niemieckim czasowników bliskoznacznych nie decyduje o aspekcie niedokonanym odpowiadającego mu zdania polskiego, wymagając obecności innych sygnifikatorów niedokonaności. Należy bowiem zaznaczyć, iż nagromadzenie czasowników bliskoznacznych może wyrażać również tzw.

\footnotetext{
${ }^{22}$ Por. wyżej.

${ }^{23}$ Por. wyżej.
} 
iteratywność wewnętrzną ${ }^{24}$, tj. powtarzanie wewnętrznych aktów zdarzenia jednorazowego, postrzeganego jako całość, co w języku polskim może zostać wyrażone dokonanym czasownikiem dystrybutywnym.

W przytoczonym poniżej zdaniu nagromadzenie czasowników bliskoznacznych niesie znaczenie niedokonaności, ponieważ mamy tu do czynienia z habitualnością całej sytuacji. Jednak w miejscu kolejno następujących po sobie czasowników wnosit [...] schodzit [...] wnosit mogłyby wystąić czasowniki dokonane wnióst [...] zszedt [...] wnióst, jeśli narrator miałby na myśli jednorazową sytuację, której jedynie wewnętrzne akty zostały powtórzone. Stąd jednoznaczne ustalenie znaczenia aspektowego takich zdań wymaga uwzględnienia innych środków językowych jako ewentualnych nośników znaczenia aspektowego. Najczęściej głównym wyznacznikiem ich znaczenia aspektowego jest kontekst zdaniowy i sytuacyjny.

Miałem młynarza maleńkiego, który po nakręceniu wnosił worek z mąką na szczyt drabiny, do spichrza, schodził po następny, znów go wnosił i tak to trwało w nieskończoność, bo wrzucone do środka worki zjeżdżały tymczasem na sam dół drabiny. (37)
Ich besaß einen kleinen Müller, der, wenn er aufgezogen wurde, einen Sack Mehl auf die Spitze einer Leiter zum Speicher hinaufschleppte, dann herunterstieg, um den nächsten zu holen, ihn wieder hinauftrug, und das so bis in die Unendlichkeit weitertrieb, weil die hineingeworfenen Säcke unterdessen bis vor die Leiter hinunterfuhren. (31-32)

\section{b. Okolicznik stets / immer}

Niemieckie okoliczniki stets i immer należą do okoliczników jednoznacznie wskazujących, iż zdarzenie, o którym mowa, było lub będzie zdarzeniem wielokrotnie się powtarzającym. W ten sposób okoliczniki te nadają zdaniu znaczenie iteratywności. Ponieważ stanowiący ich pełnoleksykalny odpowiednik polski okolicznik zawsze nie wykazuje łączliwości z czasownikami dokonanymi, ww. okoliczniki niemieckie mogą zostać uznane za samodzielne indykatory niedokonaności.

Obecny w poniżej przedstawionym przykładzie niemiecki okolicznik stets nie stanowi pełnoleksykalnego odpowiednika okolicznika polskiego, którego brak w polskim przykładzie. Wprowadzając znaczenie iteratywne stanowi on jedyny element językowy wskazujący na znaczenie aspektowe zdania.

Nic nie wiem ani o jego wystawie, ani o szczegółach wnętrza, ponieważ miejsce to, dla mnie święte, odejmowato mi dar spostrzegawczości $i$ zblizatem się tam $w$ słodkim oszołomieniu, z bijącym sercem, czując, na jaką próbę zostanie zaraz wystawiona moja, niezdolna do wyboru zachłanność. (47-48)
Über seine Schaufenster und auch über die Einzelheiten seiner Innenausstattung kann ich nichts sagen, weil mir nämlich dieser Fleck, der heilig für mich war, die Beobachtungsgabe raubte. Ich näherte mich dieser Stätte stets in einem süßen Rausch, mit pochendem Herzen, da ich im voraus fühlte, welcher Versuchung sogleich meine Gier ausgesetzt sein würde, die zu einer Wahl unfähig war. (40)

\section{c. Spójniki zdania okolicznikowego czasu während oraz (immer) wenn}

Zdanie okolicznikowe czasu ze spójnikiem während charakteryzowane jest jako zdanie wyrażające równoczesność dwóch sytuacji (por. Helbig, Buscha 2001: 600). Jak wspomniano wyżej, zaznaczenie równoczesności dwóch akcji narzuca postrzeganie przynajmniej akcji stanowiącej tło jako trwającej. Ponieważ spójnik während wprowadza zdanie dotyczące czynności stanowiącej tło, został on uznany za indykator niedokonaności.

\footnotetext{
${ }^{24}$ Termin Thelina (1978: 78).
} 
Bardzo była niezwykła historia pewnego chorego, którego przywieziono, gdy się dusit, co chwila mdlat $i$ siniat, a lusterko krtaniowe ukazywato z pozoru wolna, szeroko otwarta szpare glosowa [...] (60)
Höchst außergewöhnlich war die Krankengeschichte eines Patienten, den man $\mathrm{zu}$ ihm brachte, weil er zu ersticken schien, alle Augenblicke ohnmächtig wurde und blau anlief, während der Kehlspiegel eine scheinbar freie, breit geöffnete Stimmritze erkennen ließ $\beta$ [...] (49)

Z kolei odnoszące się do przeszłości zdanie okolicznikowe czasu ze spójnikiem (immer) wenn charakteryzowane jest jako wyrażające sytuację wielokrotnie powtarzaną w przeszłości, najczęściej o charakterze habitualnym (por. Helbig, Buscha 2001: 601). Z uwagi na trwały związek habitualności z aspektem niedokonanym zdanie okolicznikowe czasu ze spójnikiem (immer) wenn zostało uznane za nośnik znaczenia niedokonanego w języku niemieckim.

Dlatego musiałem być na wszelki wypadek sam, kiedy z cichym rozjuszeniem brałem się do torturowania pociemniałych od starości leniwców. (25)

\section{d. Konstrukcje iteratywizujące}

Za potencjalne nośniki znaczenia niedokonanego w języku niemieckim uznane zostały konstrukcje iteratywizujące 'pflegen $z u$ + bezokolicznik' oraz '(ver)suchen $z u+$ bezokolicznik'. Zgodnie $\mathrm{z}$ Deutsches Universalwörterbuch struktura 'pflegen $z u$ + bezokolicznik' ma znaczenie: „die Gewohnheit haben, etw. Bestimmtes zu tun" (Drosdowski (Ed.) 1996: 1144), wskutek czego nadaje zdaniu znaczenie habitualne, a co za tym idzie - niedokonane.

A zarazem starsi nie bez zgorszenia przypatrywali sie nowaliom technicznym i wspominali własna, podobno sroższą, a przez to i zdrowszą rzekomo młodość, co zresztą, naturalnie, puszczało się mimo ucha. (134)

Z kolei struktura '(ver)suchen $z u$ + bezokolicznik' została uznana za indykator niedokonaności (ściślej rzecz biorąc - prerezultatywności) na podstawie spostrzeżeń Czochralskiego, który stwierdza: „Drückt die präresultative Struktur ein aktives Verhalten des Subjekts aus, dann kann die präresultative Handlung gedeutet werden als eine Reihe von Versuchen, das angestrebte Resultat zu erreichen" (Czochralski 1975: 207). Spośród obecnych w materiale badawczym zdań zawierających połączenie '(ver)suchen $z u$ + bezokolicznik' za indykator znaczenia niedokonanego uznano jedynie te przypadki, w których nie stanowiło ono pełnoleksykalnego odpowiednika występujących w tekście oryginalnym czasowników próbować bądź usiłować, tzn. w których czasownik (ver)suchen pełnił funkcję czasownika posiłkowego.

Wspominam o tym tutaj dopiero, ponieważ przedziwny sentyment do baloników został mi na długie lata - kupowałem je i kryłem się z tym, aby mnie nie wyśmiewano. (136137)
Ich erwähne das erst an dieser Stelle, denn mein wundersames Gefühl für die Luftballons ist mir lange Jahre geblieben ich habe sie gekauft und es geheim zu halten versucht, damit man mich nicht auslachte. (107)

\section{Forma czasownika + spójnik zdania okolicznikowego czasu (podczas) gdy}

Do potencjalnych indykatorów niedokonaności w języku polskim został zaliczony spójnik zdania okolicznikowego czasu (podczas) gdy, należący do środków językowych wprowadzających 
znaczenie równoczesności dwóch akcji. Jak wspomniano wyżej, zaznaczenie równoczesności dwóch akcji narzuca postrzeganie przynajmniej akcji stanowiącej tło jako procesu, co wyrażane jest poprzez aspekt niedokonany.

We wszystkich niemieckich zdaniach, w których polskich odpowiednikach indykatorem niedokonaności było połączenie formy czasownika i spójnika zdania okolicznikowego czasu (podczas) $g d y$, wystąpił spójnik zdania okolicznikowego czasu während ${ }^{25}$.

Gdy głowa rodziny łykała szpady lub ogień, matka przygrywała na harmonii, a dzieci budowały $\mathrm{z}$ siebie wygibaśne piramidy $\mathrm{i}$ biegały po podwórzu, zbierając zawinięte $\mathrm{w}$ papier miedziaki - jeśli rzucano je $\mathrm{z}$ okien. (125)
Während das Haupt der Familie Degen oder Feuer schluckte, spielte die Mutter auf der Ziehharmonika, und die Kinder bildeten biegsame Pyramiden oder liefen auf dem Hof herum, um die in Papier eingewickelten Kupfermünzen aufzulesen - falls welche aus den Fenstern geworfen wurden. (99)

\section{Podsumowanie}

W tradycyjnej aspektologii zwykło się przyjmować, iż aspekt w językach słowiańskich jest kategorią czasownikową. Jednak przeprowadzone badania wskazują na wprawdzie przeważnie, lecz nie wyłącznie czasownikowy charakter tej kategorii językowej. Mimo, że w języku polskim znaczenie aspektowe jest najczęściej realizowane poprzez odpowiednią formę werbalną, to $\mathrm{w}$ większości zdań odnaleźć można także inne, nieczasownikowe elementy językowe, będące nośnikami znaczenia aspektowego. Okazuje się zatem, iż w języku polskim zazwyczaj mamy do czynienia ze swoistą redundancją w zakresie znaczenia aspektowego zdania. W języku niemieckim natomiast - z uwagi na brak czasownikowej kategorii aspektu - owe elementy nieczasownikowe najczęściej stanowią jedyne indykatory znaczenia aspektowego zdania. Niekiedy stanowią one pełnoleksykalne odpowiedniki obecnych w zdaniu polskim elementów nieczasownikowych, niekiedy zaś są elementami dodatkowymi, poprzez obecność których sygnalizowane jest znaczenie aspektowe zdania $^{26}$.

Jak wskazują przedstawione wyżej wyniki badań, w niemieckim tekście nie stwierdzono obecności samodzielnych indykatorów dokonaności. Zarówno gramatyczne (np. formy czasów Perfekt i Plusquamperfekt, forma rzeczownika w funkcji dopełnienia), jak i leksykalne (np. okoliczniki, ustalona syntagma) indykatory znaczenia dokonanego, jakie wystapily w zdaniach badanego tekstu niemieckiego, stanowią indykatory niesamodzielne w tym sensie, że sama ich obecność w zdaniu niemieckim nie przesądza o dokonanym znaczeniu odpowiadającego mu zdania polskiego. Ich funkcja jest warunkowana obecnością bądź - zwykle - brakiem w zdaniu elementów językowych niosących określone znaczenia akcjonalne.

Stosunkowo liczną grupę stanowią natomiast samodzielne indykatory niedokonaności, wśród których wymienić można:

1. Niektóre okoliczniki, a mianowicie:

a. okoliczniki duratywizujące, np. lange, eine Zeitlang,

b. okoliczniki wyrażające równoczesność czynności, np. gleichzeitig, zur gleichen Zeit, zugleich,

c. okoliczniki niosące znaczenie kontynuacji czynności, np. weiter(hin), ununterbrochen,

d. część okoliczników iteratywizujących, np. okoliczniki wprowadzające znaczenie habitualności (abends, in den kühlen Tagen des heiteren Herbstes, in den Naturkundestunden), okoliczniki immer, gewöhnlich, alle Augenblicke,

e. okoliczniki wyrażające stopniowe narastanie jakości czynności: immer + przysłówek w stopniu wyższym,

2. Prefiksy czasownikowe umher- i herum-,

3. Spójniki zdania okolicznikowego czasu (immer) wenn oraz während,

4. Spójnik złożony zdania porównawczego je...desto / je...umso,

\footnotetext{
${ }^{25}$ Por. wyżej.

${ }^{26}$ Por. przykład dotyczący niemieckich okoliczników stets / immer jako indykatorów znaczenia niedokonanego.
} 
5. Konstrukcje leksykalno-gramatyczne: 'pflegen $z u+$ bezokolicznik', '(ver)suchen $z u+$ bezokolicznik', 'imiesłów czasu przeszłego (Partizip II) + halten', 'czasownik + przyimek an + dopełnienie w celowniku'.

Mimo znacznej liczby samodzielnych indykatorów znaczenia niedokonanego, jakie wystąiły w niemieckim tekście, przeprowadzone badania wskazują na istnienie także indykatorów niesamodzielnych. Podobnie jak $\mathrm{w}$ przypadku indykatorów dokonaności, część $\mathrm{z}$ nich warunkowana jest $\mathrm{w}$ swej funkcji brakiem $\mathrm{w}$ zdaniu elementów językowych niosących określone znaczenia akcjonalne.

Jak wykazały badania, używane $\mathrm{w}$ praktyce thumaczenia środki wyrazu znaczenia aspektowego w języku niemieckim nie są tak różnorodne, jak można by się było spodziewać i jak sugerują liczne prace poświęcone temu zagadnieniu ${ }^{27}$. $Z$ całą pewnością środki językowe, jakie przytacza się w literaturze przedmiotu, mogą stanowić odpowiedniki polskich form dokonanych i niedokonanych, przy czym być może są to jedynie środki stosowane okazjonalnie bądź użyte jednorazowo dla wywołania pewnego dodatkowego wrażenia w odbiorcy komunikatu. Najczęściej bowiem stosowanym zabiegiem służącym przekazaniu znaczeń aspektowych jest wykorzystywanie okoliczników. W tym kontekście bardzo ciekawym przedsięwzięciem byłoby zbadanie możliwości wyrażania znaczenia aspektowego $\mathrm{w}$ języku niemieckim $\mathrm{z}$ uwzględnieniem dwóch różnych przekładów tego samego dzieła literackiego. Mogłoby to uwidocznić różnice występujące $\mathrm{w}$ zastosowanych przez różnych tłumaczy sposobach przekładu i w ten sposób wzbogacić wykaz tych form i struktur, do których tłumacze najczęściej się uciekają dla oddania znaczenia aspektowego wyjściowego zdania polskiego w docelowym zdaniu niemieckim.

Mimo iż wyniki przeprowadzonych badań wskazują na stosunkowo niewielką różnorodność środków wyrazu znaczeń aspektowych w języku niemieckim, nie potwierdzają one znacznych strat poznawczych u niemieckiego odbiorcy przekładu polskiego tekstu. Wskazują jedynie, iż w języku niemieckim, pozbawionym gramatycznej kategorii aspektu, znaczenie aspektowe zdania w o wiele większym stopniu niż w języku polskim stanowi efekt współwystępowania i wzajemnego oddziaływania na siebie różnych środków językowych - gramatycznych, leksykalnych, leksykalnogramatycznych oraz kontekstowych.

\footnotetext{
${ }^{27}$ Por. m.in. Czochralski (1975), Kątny (1994), Czarnecki (1998), Stawnicka (2000), Myrkin (2000), Weber (2000), Helbig, Buscha (2001), Rebotier (2004), Fabricius-Hansen (2004) oraz Baudot (2004b).
} 


\section{Bibliografia}

Andersson, S.-G. 2004. Gibt es Aspekt im Deutschen? [In:] L. Gautier, D. Haberkorn (Ed.) Aspekt und Aktionsarten im heutigen Deutsch, Tübingen: Stauffenburg Verlag, pp. 1-11.

Ballweg, J. 2004. Telizität und Atelizität im Deutschen. [In:] L. Gautier, D. Haberkorn (Ed.) Aspekt und Aktionsarten im heutigen Deutsch, Tübingen: Stauffenburg Verlag, pp. 71-86.

Baudot, D. 2004a. Aspekt und Aspektualität. Kleiner Beitrag zur Klärung von Begriffen. [In:] L. Gautier, D. Haberkorn (Ed.) Aspekt und Aktionsarten im heutigen Deutsch, Tübingen: Stauffenburg Verlag, pp. 31-42.

-----. 2004b. Aspekt und Text. Elemente einer aspektuellen Grammatik des Textes. [In:] L. Gautier, D. Haberkorn (Ed.) Aspekt und Aktionsarten im heutigen Deutsch, Tübingen: Stauffenburg Verlag, pp. 165-185.

Brinkmann, H. 1971. Die deutsche Sprache. Gestalt und Leistung. Düsseldorf: Pädagogischer Verlag Schwann.

Cockiewicz, W. 1992. Aspekt na tle systemu slowotwórczego polskiego czasownika i jego funkcyjne odpowiedniki w języku niemieckim. Kraków: Wydawnictwo Uniwersytetu Jagiellońskiego.

Comrie, B. 1976. Aspect. Cambridge: Cambridge University Press.

Czarnecki, T. 1998. Aspektualität im Polnischen und Deutschen. Bedeutungen und Formen in einer konfrontativen Übersicht. Gdańsk: Wydawnictwo Uniwersytetu Gdańskiego.

Czochralski, J. 1975. Verbalaspekt und Tempussystem im Deutschen und Polnischen. Eine Konfrontative Darstellung. Warszawa: Wydawnictwo Naukowe PWN.

Drosdowski, G. (Ed.). 1996. Deutsches Universalwörterbuch. Mannheim: Dudenverlag.

Ehrich, V., Vater, H. 1989. Das Perfekt im Dänischen und Deutschen. [In:] W. Abraham, T. Janssen (Ed.) Tempus Aspekt - Modus. Die lexikalischen und grammatischen Formen in den germanischen Sprachen, Tübingen: Max Niemeyer Verlag, pp. 103-132.

Fabricius-Hansen, C. 2004. Kontinuation und verwandte 'Phasen' - Steifkinder der Aktionsartentheorie. [In:] L. Gautier, D. Haberkorn (Ed.) Aspekt und Aktionsarten im heutigen Deutsch, Tübingen: Stauffenburg Verlag, pp. 87-102.

Flämig, W. 1970. Die Wortarten. [In:] E. Agricola, W. Fleischer, H. Protze (Ed.) Kleine Enzyklopädie. Die deutsche Sprache. T. 2. Leipzig: Bibliographisches Institut, pp. 834-908.

Helbig, G., Buscha, J. 2001. Deutsche Grammatik. Ein Handbuch für den Ausländerunterricht. Berlin-München: Langenscheidt.

Kątny, A. 1994. Zu ausgewählten Aktionsarten im Polnischen und deren Entsprechungen im Deutschen. Rzeszów: Wydawnictwo Wyższej Szkoły Pedagogicznej w Rzeszowie.

Krifka, M. 1989. Nominalreferenz, Zeitkonstitution, Aspekt, Aktionsart. Eine semantische Erklärung ihrer Interaktion. [In:] W. Abraham, T. Janssen (Ed.) Tempus - Aspekt - Modus. Die lexikalischen und grammatischen Formen in den germanischen Sprachen, Tübingen: Max Niemeyer Verlag, pp. 227-258.

Lem, S. 1968. Wysoki Zamek. Warszawa: Czytelnik.

-----. 1990. Das Hohe Schloß. Berlin: Suhrkamp Taschenbuch Verlag.

Markowski, A. (Ed.). 1999. Nowy stownik poprawnej polszczyzny. Warszawa: Wydawnictwo Naukowe PWN.

Młynarczyk, A. 2004. Aspectual Pairing in Polish. Utrecht: Landelijke Onderzoekschool Taalwetenschap.

Piprek, J. 1989. Wielki słownik niemiecko-polski z suplementem. T. 1-2. Warszawa: Wiedza Powszechna.

Piprek, J. 1990. Wielki stownik polsko-niemiecki z suplementem. T. 1-2. Warszawa: Wiedza Powszechna.

Sapir, E. 1949. Culture, Language and Personality. Berkeley: University of California Press.

Schanen, F. 2004. Vorgangsbezeichnungen. Kategorien oder kontekstuelle Erscheinungen? [In:] L. Gautier, D. Haberkorn (Ed.) Aspekt und Aktionsarten im heutigen Deutsch, Tübingen: Stauffenburg Verlag, pp. 12-30.

Schwall, U. 1991. Aspektualität. Eine semantisch-funktionelle Kategorie. Tübingen: Gunter Narr Verlag.

Stawnicka, J. 2000. Einige Bemerkungen zu den Entsprechungen der russischen Aktionsarten im Deutschen. [In:] A. Kątny (Ed.) Aspektualität in germanischen und slawischen Sprachen, Poznań: Wydawnictwo Naukowe UAM, pp. 195-203.

Szymczak, M. 1988. Stownik języka polskiego. T. 1-3. Warszawa: Wydawnictwo Naukowe PWN.

Thelin, N. B. 1978. Towards a theory of aspect, tense and actionality in Slavic. Uppsala: Almquist \& Wiksell.

Vater, H. 2000. Das deutsche Perfekt - Tempus oder Aspekt oder beides? [In:] A. Kątny (Ed.) Aspektualität in germanischen und slawischen Sprachen, Poznań: Wydawnictwo Naukowe UAM, pp. 87-107.

Verkuyl, H. J. 1999. Aspectual issues. Structuring time and quantity. CSLI Lecture Notes, vol. 98.

Whorf, B. 1956. Language, Thought, and Reality: Selected Writings of Benjamin Lee Whorf. Cambridge: MIT Press.

Wojtasiewicz, O. 1996. Wstęp do teorii thumaczenia. Warszawa: TEPIS. 